\title{
EVALUATION OF THE ENVIRONMENTAL STATE OF THE WESTERN SECTOR OF SEPETIBA BAY (SE BRAZIL): TRACE METAL CONTAMINATION
}

\section{Shéron Joyce Díaz Morales ${ }^{1}$, Josefa Varela Guerra ${ }^{1}$, Márcia ANDréia da Silva Nunes², ARIadNe MARRA DE SOUZA ${ }^{3}$ AND MAURo CÉSAR GERALDES ${ }^{2 *}$}

1 Universidade do Estado do Rio de Janeiro, Faculdade de Oceanografia, Rua São Francisco Xavier, 524, 4 andar, bloco E, sala 4028, Maracanã, Rio de Janeiro, RJ, Brazil

2 Universidade do Estado do Rio de Janeiro, Faculdade de Geologia, Rua São Francisco Xavier, 524, sala 4024, bloco A, Maracanã, Rio de Janeiro, RJ, Brazil

3 Universidade Federal do Espírito Santo (UFES), Centro de Ciências Exatas, Naturais e da Saúde, Alto Universitário s/n, Caixa Postal 16, Alegre - ES, Brazil.

*Corresponding aUthor, geraldes@uerj.br

Received on 4 January 2019

Received in revised form on 18 June 2019

Accepted on 19 June 2019

Editor: Maria Virginia Alves Martins, Universidade do Estado do Rio de Janeiro
Citation:

Díaz Morales, S.J., Guerra, J.V., Nunes, M.A.S, Souza, A.M., Geraldes, M.C., 2019. Evaluation of the environmental state of the western sector of Sepetiba Bay (SE Brazil): trace metal contamination. Journal of Sedimentary Environments, 4 (2): 174-188.

\section{Abstract}

Sepetiba Bay located in Rio de Janeiro State (RJ), Southeast Brazil, is a region under heavy influence of seaports and mining. This feature puts at risk the quality of the local water system, especially due to the deposition of trace metals on the sediments. This work aimed to report the values of total concentrations of Ag, As, Cd, Co, Cr, Cu, Li, Mn, Ni, Pb, Sr, $\mathrm{Zn}$ and $\mathrm{Hg}$ obtained in bottom surface sediments collected in Nov/2010 in the Western sector of Sepetiba Bay, through the Plasma Spectrometer (ICP-OES). The average concentrations of $\mathrm{Ag}(0.40 \mu \mathrm{g} / \mathrm{g}), \mathrm{Cd}(0.76 \mu \mathrm{g} / \mathrm{g}), \mathrm{Cu}(62.59$

\section{Introduction}

Sepetiba Bay is a semi enclosed coastal water body with a surface area of $520 \mathrm{~km}^{2}$ (Rio de Janeiro, 1998). It is located at about $44^{\circ} \mathrm{W}$ and $23^{\circ} \mathrm{S}$, at $60 \mathrm{~km}$ west of the metropolitan region of Rio de Janeiro, in southeast Brazil (Cunha et al., 2006; Pellegatti, 2000). According to Santos (2007) the marginal region of Sepetiba Bay is being used for the development of numerous agricultural, commercial, industrial, mining and port activities. We can mention for example the Itaguaí and Guaíba Terminal ports and the industries Gerdau, Petrobrás, National Steel Company (CSN), and the deactivated mining company Ingá. Wasserman et al. (2001) highlight that the construction of the large Sepetiba Port, in the early 70s, encouraged the industrial investment in this region. The industries and other anthropogenic activities are using the rivers and canals as recipients of effluents. Materials and contaminants introduced in Sepetiba Bay are altering this ecosystem according to Wasserman et al. (2001). $\mu \mathrm{g} / \mathrm{g}), \mathrm{Li}(43.29 \mu \mathrm{g} / \mathrm{g}), \mathrm{Ni}(16.65 \mu \mathrm{g} / \mathrm{g}), \mathrm{Pb}(20.08 \mu \mathrm{g} / \mathrm{g}), \mathrm{Sr}$ (389.64 $\mu \mathrm{g} / \mathrm{g})$ and $\mathrm{Zn}(184.2 \mu \mathrm{g} / \mathrm{g})$ exceeded the limits allowed by Brazilian legislation, and are, in addition, above the natural values found in Ribeira Bay (RJ), the considered control region. It is necessary to monitor this area, due to its economic and environmental importance.

Keywords: Total Trace Metals. Sediments. Coastal area. Contamination.

Trace metals resulting from this industrial pole are the main contaminants in Sepetiba Bay. Their properties and cumulative character make the situation critical, especially for aquatic biota (Gomes et al., 2019). The Mercantile Company Ingá (Fig. 1), disabled in 2008, was one of the industries that most contributed to the addition of contaminants in Sepetiba Bay, especially $\mathrm{Cd}$ and $\mathrm{Zn}$ (Gomes et al., 2009). Its installation occurred in the decade of 60 , in the region of Madeira Island, in the Itaguaí town, beginning the electroplating process and evolving to zinc processing in 1966, and later, in 1974, for the processing of cadmium (Barcellos, 1995).

Lacerda and Molisani (2006) monitored the concentrations of metals in Sepetiba Bay between 1978 and 2002, through the analysis of bivalve mollusks, and found that the samples collected in 1996 had the highest Cd (29 $\mu \mathrm{g} / \mathrm{g})$ and $\mathrm{Zn}(80.72 \mu \mathrm{g} / \mathrm{g})$ concentrations. These authors attributed these high concentrations of metals to the 
introduction of pollutants into the Sepetiba Bay through the rupture of a dam that isolated the environmental liabilities (ore tailings) produced by the deactivated Ingá Company after a heavy rainy period. According to PACS (2012) this disruption seriously affected the biota, resulting in a decrease of fish, of about $60 \%$.

According to Lacerda et al. (1987), another main entrance of metals in Sepetiba Bay is fluvial and takes place mainly through the Guandu River and São Francisco
RESEARCH PAPER

Canal, with emphasis on national water transport. Both rivers are used by this regional industrial complex contributing with approximately $75 \%$ of the entrance of metals into this system.

The increase in the frequency of dredging due to the expansion of the seaport activities has also been an additional factor related to the increased availability of metals within the bay (Molisani et al., 2004).

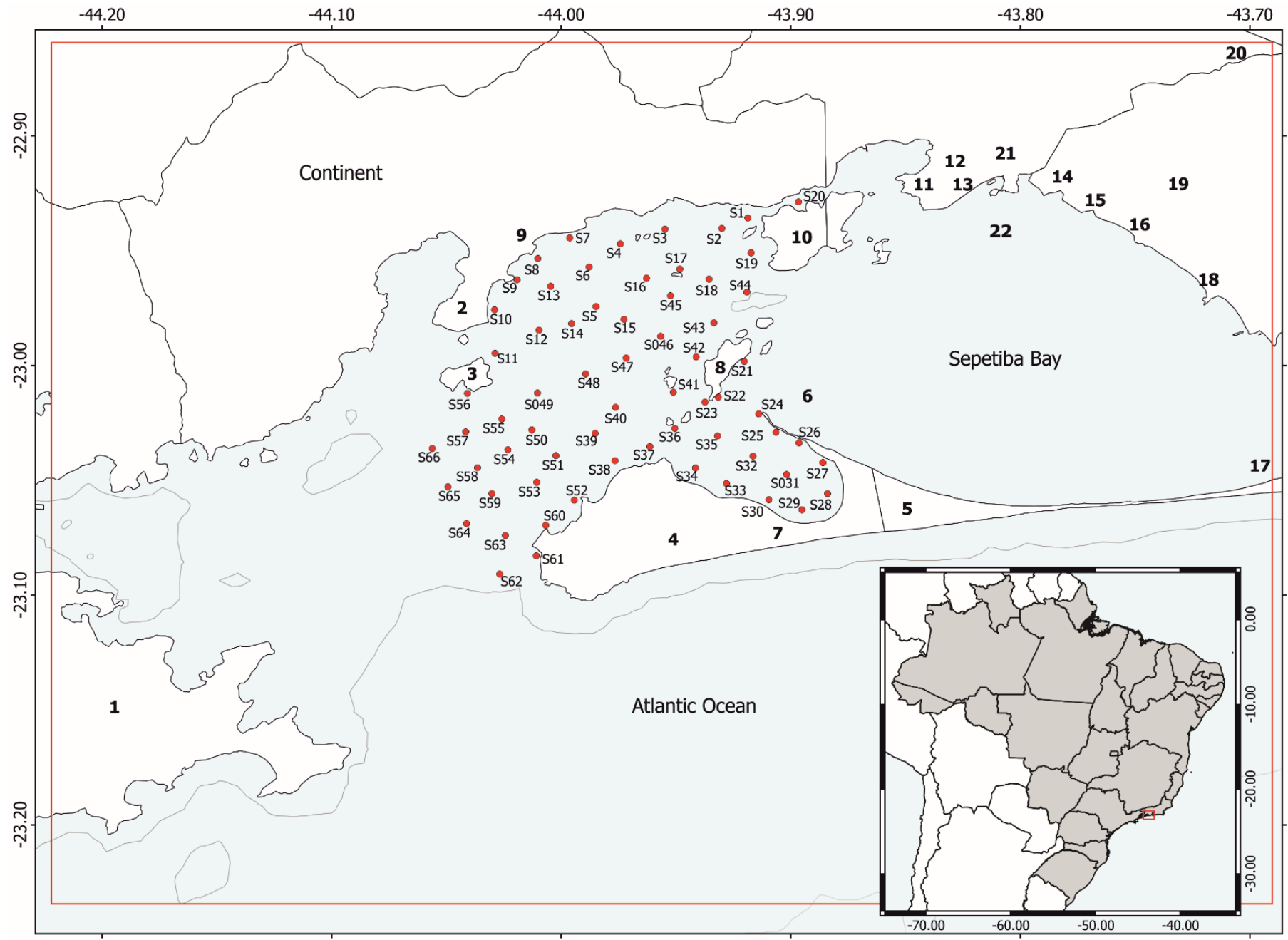

Fig. 1. Study area (Sepetiba Bay, RJ, Brazil) with the location of the points where surface sediment samples were collected (stations S1 S66): 1- Grande Island; 2- Mangaratiba; 3- Guaíba Island (Port terminal); 4- Marambaia hill; 5- Marambaia sand spit (external zone); 6Ponta da Pombeba; 7- Marambaia Bay; 8- Jaguanum Island; 9- Saí River; 10- Itacuruçá Island; 11- Madeira Island (Port of Itaguaí / Sepetiba); 12- Ingá (shut down industry - metallic waste); 13- Engenho Bay; 14- Guarda River; 15- São Francisco Channel; 16- Guandu Channel; 17- Marambaia sand spit (a more inside zone); 18- Sepetiba (town); 19- Santa Cruz; 20- Nova Iguaçu; 21- Itaguaí; 22- Dredging area of Port of Sepetiba.

The accelerated urban and industrial expansion without a prior planning are causing serious negative impact since Sepetiba Bay has inestimable social, environmental and economic value. Its vast area of mangrove forest added up to the physicochemical and biological properties of the region contribute to the high biodiversity of this bay. Sepetiba Bay is the habitat for several species, including some endangered ones, besides having great importance for the fisheries sector of the Rio de Janeiro State (Cardoso et al., 2019). Therefore, the environmental monitoring of this area is of great importance in order to take protective measures and prevent the degradation of this ecosystem. The objective of this study was to determine the total concentrations of trace elements ( $\mathrm{Ag}, \mathrm{As}, \mathrm{Cd}, \mathrm{Co}, \mathrm{Cr}, \mathrm{Cu}$, 
$\mathrm{Hg}, \mathrm{Li}, \mathrm{Mn}, \mathrm{Ni}, \mathrm{Pb}, \mathrm{Sr}, \mathrm{U}, \mathrm{Zn}$ ) in bottom surface sediments collected in the western sector of Sepetiba Bay - RJ, Brazil.

\section{Materials and Methods}

The campaigns for sampling surface bottom sediments were carried out on November 10, 22 and 23, 2010, in the western sector of Sepetiba Bay - RJ, a region bordering Ilha Grande Bay - RJ. The sampling network was composed by 66 stations. Stations were named S01 to S66 ( $\mathrm{S}=$ Sepetiba) (Fig. 1). The samples location is included in Table 1. The sediment samples were collected with a Van Veen Grab.

Sediment samples were taken from the central portion of the Van Veen Grab to avoid the collection of sediment that has been in contact with the equipment. The samples were stored in plastic containers, properly coded, and stowed in a cooler with ice until the arrival to the laboratory, where they were stored in a freezer at a temperature $<10^{\circ}$ Celsius.

The preparation of the samples for analysis of trace elements followed the techniques used by Cunha et al. (2009) in a study developed in the eastern sector of Sepetiba Bay.

The drying process was conducted in the Geological Samples Preparation Laboratory from the Universidade do Estado do Rio de Janeiro (UERJ) in an oven at temperature of about $80^{\circ}$ Celsius. Then, the sediment samples were disaggregated and homogenized, with the aid of a mortar and pistil, and sieved on a set of sieves with meshes of 1 $\mathrm{mm}, 0.5 \mathrm{~mm}$ and $0.072 \mathrm{~mm}$ diameters. The sediment fractions $<0.072 \mathrm{~mm}$ were kept in small polyethylene bottles for posterior analysis of trace elements.

Aliquots of the samples were sent to the ACTLABS laboratory (Activation Laboratories Ltd., Canada) in order to analyze the total elemental concentrations of trace elements. The procedure involved the use of hydrofluoric acid ( $\mathrm{HF})$ and hydrochloric acid $(\mathrm{HCl})$. One aliquot of 0.25 $\mathrm{g}$ of the sample was, initially, digested with hydrofluoric acid (HF) and then in a programmed heating system, it was added a solution of nitric $\left(\mathrm{HNO}_{3}\right)$ and perchloric $\left(\mathrm{HClO}_{4}\right)$ acids to the sample until it became vaporized. After the remaining solution had been vaporized to the point of dryness, it was solubilized with hydrochloric acid $(\mathrm{HCl})$. Laboratory standards and certified reference materials were used in quality control. Elemental concentrations were analyzed with the Plasma Spectrophotometer (ICPOES) Varian Vista. Fourteen trace elements were analyzed: $\mathrm{Ag}, \mathrm{As}, \mathrm{Cd}, \mathrm{Co}, \mathrm{Cr}, \mathrm{Cu}, \mathrm{Hg}, \mathrm{Li}, \mathrm{Mn}, \mathrm{Ni}, \mathrm{Pb}, \mathrm{Sr}, \mathrm{U}$ and $\mathrm{Zn}$. The Brazilian National Advice of the Environment (CONAMA) Resolution 454/2012 does not stablish limits for $\mathrm{Fe}$ and $\mathrm{Al}$ and thus the distribution of these elements is not discussed in this work.

In this study, the adopted reference limits were the smallest values allowed for the CONAMA Resolution 454/2012, Canadian Sediment Quality Guidelines for the
RESEARCH PAPER

Protection of Aquatic Life (Canadian ISQG, 1999), National Oceanic and Atmospheric Administration (NOAA, 1999) and Florida Sediment Quality Assessment Guidelines (Florida SQAG'S), besides the background values supplied by Turekian and Wedepohl (1961) for total elemental concentrations. It is worth noting that for the use of the reference values presented by Turekian and Wedepohl (1961), the present study made an average between the background obtained in shales and in sandstones, since the studied region has heterogenous granulometric characteristics, varying between clayey to sandy.

\section{Results and Discussion}

The total concentration values of metals in the analyzed bottom surface sediment samples of Sepetiba Bay, as well as the averages, standard deviations and minimum and maximum values can be found in Table 1. Distribution maps of the elemental concentrations in the study area are presented in Figures 2-4.

The levels found were compared with Brazilian and international reference limits. The values obtained in all the analyzed stations exceeded, in at least one of the elements (Ag, As, Cd, Co, Cr, Cu, Li, Mn, Ni, Pb, Sr, Zn and Hg), the background values of Turekian and Wedepohl (1961) and the levels allowed by both Brazilian and international legislation, for total concentration of metals in sediments. Stations S16, located north of Jaguanum Island and west of Itacuruça Island, and S30, located in Saco da Marambaia, presented the highest number of metals (Ag, As, Cd, Co, Cr, Cu, Li, Mn, Ni, Pb, Sr, Zn) with values above those allowed.

Nine from sixteen of the analyzed elements presented average concentrations above the world reference value (Table 1), including Ag $(0.4 \mu \mathrm{g} / \mathrm{g}), \mathrm{Cd}(0.8 \mu \mathrm{g} / \mathrm{g}), \mathrm{Cu}(62.6$ $\mu \mathrm{g} / \mathrm{g}), \mathrm{Li}(43.3 \mu \mathrm{g} / \mathrm{g}), \mathrm{Mn}(679.7 \mu \mathrm{g} / \mathrm{g}), \mathrm{Ni}(16.7 \mu \mathrm{g} / \mathrm{g}), \mathrm{Pb}$ $(20.1 \mu \mathrm{g} / \mathrm{g}), \operatorname{Sr}(389.6 \mu \mathrm{g} / \mathrm{g})$ and $\mathrm{Zn}(184.8 \mu \mathrm{g} / \mathrm{g})$.

The percentage of the stations with trace element concentrations exceeding the adopted limits (mentioned in Table 1), shows that the Western Sector of Sepetiba Bay presents a scenario of elemental enrichment by $\mathrm{Ag}(100 \%)$, Cd (100\%), Zn (89\%), Mn (79\%), Cu (73\%), Li (65\%), Ni (69\%), $\mathrm{Pb}(68 \%), \mathrm{Sr}(67 \%)$ and $\mathrm{Cr}(52 \%)$.

\subsection{Essential trace Elements ( $A s, C r, C u, M n, Z n, A l$ and Fe)}

The essential trace elements are those that play a role in biological metabolism (As, Cr, Cu, Mn, Zn, Al and Fe). However, even these elements, under certain environmental conditions and depending on their concentrations, can result in negative impact on aquatic ecosystems (Patterson et al., 1976; Guilherme et al., 2005). 

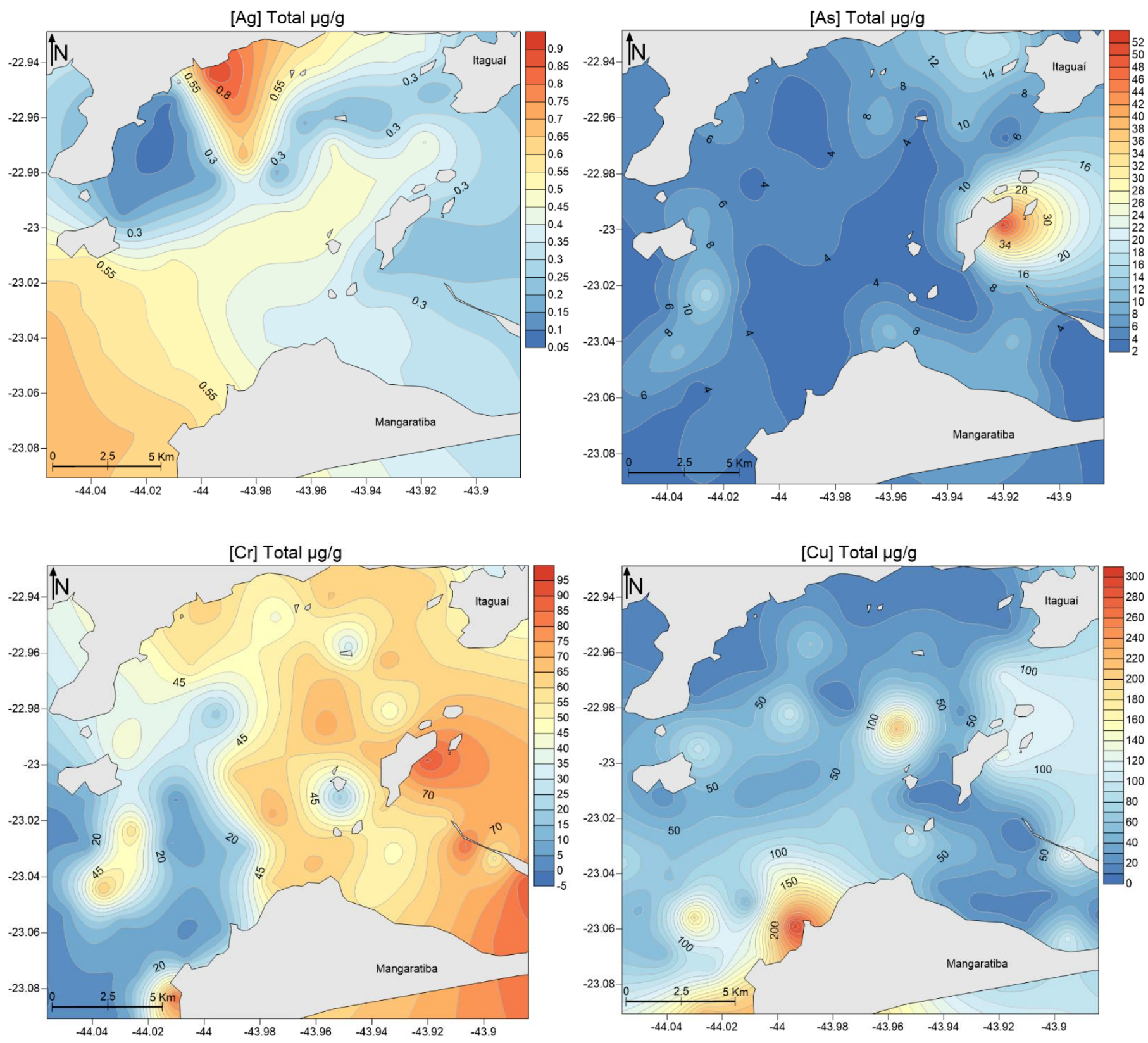

Fig. 2. Map of distribution of the total trace element concentration of $\mathrm{Ag}$, As, $\mathrm{Cr}$ and $\mathrm{Cu}$.

Arsenic (Appendix 1A) concentrations ranged from $<3$ to $53 \mu \mathrm{g} / \mathrm{g}$, with an average of $6.50 \pm 6.79 \mu \mathrm{g} / \mathrm{g}$. Chromium and $\mathrm{Cu}$ (Appendix $1 \mathrm{~B}$ and $\mathrm{C}$ ) varied between 3 to $92 \mu \mathrm{g} / \mathrm{g}$ and 9 to $303 \mu \mathrm{g} / \mathrm{g}$ respectively (averages of $46.98 \pm 25.84 \mu \mathrm{g} / \mathrm{g}$ and $62.59 \pm 59.85 \mu \mathrm{g} / \mathrm{g}$, respectively; Table 1). Manganese and $\mathrm{Zn}$ (Appendix $2 \mathrm{~A}$ and $\mathrm{B}$ ) concentrations ranged between 80 to $2450 \mu \mathrm{g} / \mathrm{g}$ and 19 to $478 \mu \mathrm{g} / \mathrm{g}$, respectively (averages of $679.70 \pm 353.22 \mu \mathrm{g} / \mathrm{g}$ and $184.82 \pm 103.54 \mu \mathrm{g} / \mathrm{g}$, respectively; Table 1). Aluminum and $\mathrm{Fe}$ levels fluctuated between 0.47 and $9.55 \%$ and 0.09 and $7.93 \%$, respectively (averages of 3.72 $\pm 1.87 \%$ and $3.20 \pm 1.93 \%$, respectively; Table 1 ). 
Tab. 1. Total trace elemental concentrations per station (S1 - S66), average, standard deviation, minimum and maximum values. Values in $\mu \mathrm{g} / \mathrm{g}$ dry weight.

\begin{tabular}{|c|c|c|c|c|c|c|c|c|c|c|c|c|c|c|c|}
\hline \multicolumn{3}{|c|}{ Elemental concentrations $(\mu \mathrm{g} / \mathrm{g})$} & Ag & As & Cd & Co & $\mathrm{Cr}$ & $\mathrm{Cu}$ & Li & Mn & $\mathrm{Ni}$ & $\mathbf{P b}$ & Sr & $\mathrm{Zn}$ & $\mathrm{Hg}$ \\
\hline \multicolumn{3}{|c|}{ CONAMA 344/2004 ( $\mu \mathrm{g} / \mathrm{g})$} & & 8.2 & 1.2 & & 81 & 34 & & & 20.9 & 46.7 & & 150 & 0.15 \\
\hline \multicolumn{3}{|c|}{ SQAGs Florida (TEL)* ( $\mu \mathrm{g} / \mathrm{g})$} & 0.733 & 7.24 & 0.676 & & 52.3 & 18.7 & & & 15.9 & 30.2 & & 124 & 0.13 \\
\hline \multicolumn{3}{|c|}{ Canadian ISQGs (ISQG) $* *(\mu \mathrm{g} / \mathrm{g})$} & & 7.24 & 0.7 & & 52.3 & 18.7 & & & & 30.2 & & 124 & 0.13 \\
\hline \multicolumn{3}{|c|}{ NOAA $(\mu g / g)$} & 0.73 & 7.24 & 0.68 & & 52.3 & 18.7 & & & 15.9 & 30.24 & & 124 & 0.13 \\
\hline Stations & Latitude & Longitude & [total] & [total] & [total] & [total] & [total] & [total] & [total] & [total] & [total] & [total] & [total] & [total] & [total] \\
\hline S02 & 2256.420 & 4355.802 & 0.40 & 17 & 2.7 & 10 & 62 & 18 & 80 & 719 & 23 & 25 & 240 & 398 & $<1$ \\
\hline S03 & 2256.439 & 4357.288 & 0.50 & 10 & 1.9 & 11 & 66 & 16 & 78 & 790 & 26 & 22 & 185 & 443 & $<1$ \\
\hline S04 & 2256.821 & 4358.453 & 0.60 & 6 & 0.9 & 10 & 43 & 16 & 76 & 817 & 26 & 22 & 291 & 296 & $<1$ \\
\hline S05 & 2258.460 & 4359.089 & 0.70 & 3 & 0.4 & 5 & 42 & 16 & 47 & 371 & 17 & 21 & 522 & 136 & $<1$ \\
\hline S06 & 2257.427 & 4359.271 & 0.80 & 3 & 0.7 & 7 & 51 & 64 & 49 & 529 & 17 & 19 & 615 & 174 & $<1$ \\
\hline S07 & 2256.666 & 4359.779 & 0.90 & 4 & 0.8 & 10 & 62 & 28 & 69 & 728 & 23 & 25 & 229 & 275 & $<1$ \\
\hline S08 & 2257.205 & 4400.611 & 0.10 & 5 & 0.9 & 10 & 58 & 16 & 74 & 751 & 24 & 26 & 211 & 241 & $<1$ \\
\hline S09 & 2257.759 & 4401.154 & 0.11 & 8 & 0.4 & 7 & 45 & 14 & 53 & 512 & 17 & 23 & 644 & 134 & $<1$ \\
\hline S10 & 2258.544 & 4401.742 & 0.12 & 4 & 0.3 & 7 & 38 & 18 & 47 & 1120 & 15 & 21 & 893 & 108 & $<1$ \\
\hline S11 & 2259.681 & 4401.729 & 0.13 & 9 & 0.3 & 6 & 45 & 98 & 51 & 622 & 17 & 18 & 614 & 142 & $<1$ \\
\hline S12 & 2259.076 & 4400.581 & 0.14 & 3 & 0.3 & 4 & 35 & 46 & 40 & 351 & 16 & 19 & 648 & 104 & $<1$ \\
\hline S13 & 2257.932 & 4400.277 & 0.15 & 4 & 0.5 & 9 & 55 & 17 & 67 & 624 & 22 & 22 & 422 & 194 & $<1$ \\
\hline S14 & 2258.905 & 4359.729 & 0.16 & 6 & 0.3 & 4 & 16 & 103 & 24 & 789 & 10 & 13 & 797 & 105 & $<1$ \\
\hline S15 & 2258.793 & 4358.361 & 0.17 & 6 & 1.2 & 9 & 55 & 14 & 66 & 547 & 25 & 21 & 219 & 250 & $<1$ \\
\hline S16 & 2257.717 & 4357.773 & 0.18 & 10 & 1.0 & 11 & 63 & 30 & 62 & 513 & 23 & 23 & 244 & 246 & $<1$ \\
\hline S17 & 2257.478 & 4356.900 & 0.19 & 3 & 0.8 & 3 & 30 & 40 & 32 & 352 & 9 & 12 & 956 & 126 & $<1$ \\
\hline S18 & 2257.743 & 4356.137 & 0.20 & 12 & 0.9 & 9 & 69 & 22 & 59 & 513 & 22 & 33 & 182 & 227 & $<1$ \\
\hline S19 & 2257.056 & 4355.037 & 0.21 & 8 & 1.7 & 10 & 56 & 15 & 71 & 601 & 24 & 21 & 161 & 313 & $<1$ \\
\hline S20 & 2255.725 & 4353.800 & 0.22 & 5 & 0.3 & 5 & 30 & 71 & 44 & 500 & 12 & 35 & 457 & 159 & $<1$ \\
\hline$S 21$ & 2259.894 & 4355.217 & 0.23 & 53 & 0.7 & 9 & 92 & 127 & 37 & 649 & 18 & 24 & 171 & 263 & 8 \\
\hline S22 & 2300.826 & 4355.895 & 0.24 & 6 & 0.9 & 9 & 60 & 16 & 65 & 577 & 24 & 18 & 354 & 229 & $<1$ \\
\hline S23 & 2300.956 & 4356.243 & 0.25 & 3 & 0.9 & 8 & 61 & 15 & 60 & 1040 & 23 & 20 & 276 & 197 & $<1$ \\
\hline S24 & 2301.264 & 4354.838 & 0.26 & 8 & 2.5 & 9 & 57 & 15 & 57 & 647 & 22 & 21 & 152 & 248 & $<1$ \\
\hline S25 & 2301.740 & 4354.390 & 0.27 & 8 & 1 & 11 & 88 & 15 & 49 & 961 & 20 & 28 & 159 & 249 & $<1$ \\
\hline S26 & 2302.022 & 4353.784 & 0.28 & 3 & 0.7 & 6 & 52 & 129 & 28 & 570 & 12 & 19 & 173 & 206 & $<1$ \\
\hline S27 & 2302.535 & 4353.161 & 0.29 & 3 & 0.9 & 9 & 89 & 47 & 29 & 1040 & 14 & 26 & 235 & 184 & $<1$ \\
\hline S28 & 2303.348 & 4353.041 & 0.30 & 3 & 1.1 & 11 & 85 & 12 & 52 & 1100 & 23 & 29 & 165 & 290 & $<1$ \\
\hline S29 & 2303.766 & 4353.710 & 0.31 & 3 & 0.9 & 9 & 81 & 106 & 54 & 786 & 21 & 23 & 221 & 307 & $<1$ \\
\hline S30 & 2303.503 & 4354.575 & 0.32 & 9 & 1.9 & 13 & 71 & 20 & 63 & 1440 & 24 & 22 & 178 & 356 & $<1$ \\
\hline S31 & 2302.847 & 4354.111 & 0.33 & 3 & 1.5 & 11 & 72 & 15 & 61 & 860 & 24 & 21 & 176 & 329 & $<1$ \\
\hline S32 & 2302.366 & 4354.989 & 0.34 & 11 & 1.8 & 9 & 64 & 34 & 56 & 645 & 23 & 19 & 183 & 310 & $<1$ \\
\hline S33 & 2303.082 & 4355.682 & 0.35 & 8 & 2.2 & 11 & 60 & 16 & 61 & 955 & 23 & 23 & 179 & 478 & $<1$ \\
\hline S34 & 2302.676 & 4356.491 & 0.36 & 10 & 2.4 & 9 & 51 & 25 & 58 & 826 & 22 & 17 & 167 & 249 & $<1$ \\
\hline S35 & 2301.839 & 4355.915 & 0.37 & 3 & 0.7 & 6 & 47 & 51 & 50 & 553 & 19 & 34 & 377 & 183 & $<1$ \\
\hline S36 & 2301.643 & 4357.031 & 0.38 & 4 & 0.9 & 9 & 65 & 90 & 66 & 537 & 24 & 19 & 309 & 277 & $<1$ \\
\hline S37 & 2302.118 & 4357.683 & 0.39 & 11 & 0.8 & 9 & 66 & 61 & 65 & 612 & 26 & 21 & 290 & 262 & $<1$ \\
\hline S38 & 2302.485 & 4358.596 & 0.40 & 3 & 0.9 & 9 & 60 & 107 & 63 & 720 & 29 & 27 & 345 & 254 & $<1$ \\
\hline S39 & 2301.772 & 4359.112 & 0.41 & 3 & 0.4 & 3 & 18 & 80 & 20 & 350 & 8 & 16 & 228 & 106 & $<1$ \\
\hline S40 & 2301.092 & 4358.580 & 0.42 & 3 & 0.6 & 8 & 73 & 76 & 51 & 519 & 20 & 21 & 259 & 161 & $<1$ \\
\hline S41 & 2300.697 & 4357.071 & 0.43 & 3 & 0.3 & 1 & 15 & 9 & 16 & 256 & 7 & 8 & 1380 & 66 & $<1$ \\
\hline S42 & 2259.775 & 4356.476 & 0.44 & 7 & 0.3 & 8 & 68 & 26 & 44 & 604 & 18 & 23 & 234 & 150 & $<1$ \\
\hline S43 & 2258.885 & 4356.008 & 0.45 & 6 & 0.4 & 8 & 44 & 21 & 54 & 396 & 20 & 15 & 606 & 149 & $<1$ \\
\hline S44 & 2258.085 & 4355.148 & 0.46 & 3 & 0.5 & 8 & 61 & 117 & 58 & 432 & 24 & 21 & 204 & 219 & $<1$ \\
\hline S45 & 2258.178 & 4357.143 & 0.47 & 3 & 0.7 & 8 & 66 & 43 & 58 & 442 & 24 & 21 & 191 & 194 & $<1$ \\
\hline S46 & 2259.235 & 4357.401 & 0.48 & 3 & 0.3 & 8 & 74 & 223 & 48 & 597 & 20 & 22 & 250 & 210 & $<1$ \\
\hline S47 & 2259.804 & 4358.303 & 0.49 & 3 & 0.5 & 7 & 60 & 61 & 43 & 458 & 18 & 19 & 241 & 118 & $<1$ \\
\hline S48 & 2300.220 & 4359.361 & 0.5 & 6 & 0.3 & 8 & 62 & 30 & 59 & 453 & 24 & 19 & 249 & 130 & $<1$ \\
\hline S49 & 2300.718 & 4400.620 & 0.51 & 3 & 0.3 & 1 & 3 & 28 & 6 & 179 & 3 & 13 & 187 & 19 & $<1$ \\
\hline S50 & 2301.681 & 4400.767 & 0.52 & 3 & 0.3 & 2 & 5 & 72 & 7 & 2450 & 4 & 11 & 617 & 67 & $<1$ \\
\hline S51 & 2302.353 & 4400.140 & 0.53 & 3 & 0.3 & 1 & 11 & 128 & 6 & 367 & 6 & 14 & 242 & 69 & $<1$ \\
\hline S52 & 2303.516 & 4359.659 & 0.54 & 3 & 0.3 & 1 & 8 & 303 & 6 & 80 & 1 & 5 & 431 & 135 & $<1$ \\
\hline S53 & 2303.050 & 4400.640 & 0.55 & 5 & 0.3 & 2 & 8 & 47 & 7 & 1090 & 7 & 22 & 643 & 39 & $<1$ \\
\hline S54 & 2302.200 & 4401.393 & 0.56 & 8 & 0.4 & 5 & 44 & 74 & 42 & 514 & 16 & 21 & 423 & 116 & $<1$ \\
\hline S55 & 2301.399 & 4401.554 & 0.57 & 16 & 0.3 & 9 & 61 & 54 & 61 & 772 & 25 & 18 & 255 & 152 & $<1$ \\
\hline
\end{tabular}


Tab. 1. (cont.) Total trace elemental concentrations per station (S1 - S66), average, standard deviation, minimum and maximum values. Values in $\mu \mathrm{g} / \mathrm{g}$ dry weight.

\begin{tabular}{|c|c|c|c|c|c|c|c|c|c|c|c|c|c|c|c|}
\hline \multicolumn{3}{|c|}{ Elemental concentrations $(\mu \mathrm{g} / \mathrm{g})$} & $\mathrm{Ag}$ & As & Cd & Co & $\mathrm{Cr}$ & $\mathrm{Cu}$ & Li & Mn & $\mathbf{N i}$ & $\mathbf{P b}$ & $\mathrm{Sr}$ & Zn & $\mathrm{Hg}$ \\
\hline S56 & 2300.726 & 4402.449 & 0.58 & 4 & 0.3 & 1 & 11 & 20 & 7 & 367 & 3 & 9 & 1520 & 27 & $<1$ \\
\hline S57 & 2301.730 & 4402.498 & 0.59 & 4 & 0.3 & 1 & 5 & 59 & 5 & 725 & 2 & 28 & 530 & 34 & $<1$ \\
\hline S58 & 2302.669 & 4402.187 & 0.60 & 11 & 0.3 & 10 & 68 & 61 & 64 & 411 & 26 & 20 & 193 & 142 & $<1$ \\
\hline S59 & 2303.346 & 4401.814 & 0.61 & 3 & 0.3 & 1 & 12 & 186 & 6 & 1550 & 1 & 14 & 434 & 108 & $<1$ \\
\hline S60 & 2304.173 & 4400.404 & 0.62 & 5 & 0.3 & 1 & 9 & 142 & 9 & 1160 & 5 & 13 & 1200 & 97 & $<1$ \\
\hline S61 & 2304.972 & 4400.653 & 0.63 & 3 & 0.3 & 7 & 87 & 196 & 14 & 939 & 10 & 26 & 370 & 147 & $<1$ \\
\hline S62 & 2305.446 & 4401.608 & 0.64 & 4 & 0.3 & 1 & 7 & 220 & 4 & 469 & 7 & 10 & 581 & 101 & $<1$ \\
\hline S63 & 2304.440 & 4401.459 & 0.65 & 6 & 0.3 & 1 & 7 & 90 & 6 & 793 & 6 & 15 & 349 & 68 & $<1$ \\
\hline S64 & 2304.126 & 4402.473 & 0.66 & 3 & 0.3 & 1 & 9 & 50 & 6 & 609 & 2 & 11 & 323 & 39 & $<1$ \\
\hline S65 & 2303.169 & 4402.959 & 0.67 & 8 & 0.3 & 1 & 6 & 47 & 6 & 644 & 4 & 22 & 338 & 28 & $<1$ \\
\hline S66 & 2302.168 & 4403.371 & 0.68 & 3 & 0.3 & 1 & 7 & 86 & 4 & 339 & 3 & 11 & 419 & 43 & $<1$ \\
\hline \multicolumn{3}{|c|}{ Average } & 0.4 & 6.4 & 1.0 & 6.6 & 46.9 & 63.3 & 42.8 & 681 & 16.5 & 20.0 & 392.9 & 182.7 & \\
\hline \multicolumn{3}{|c|}{ Standard Deviation } & 0.2 & 6.8 & 0.6 & 3.6 & 25.8 & 59.9 & 23.9 & 353 & 8.2 & 6.0 & 287.1 & 103.5 & \\
\hline \multicolumn{3}{|c|}{ Minimum } & 0.1 & 3.0 & 0.3 & 1.0 & 3.0 & 9.0 & 4.0 & 80 & 1.0 & 5.0 & 152.0 & 19.0 & $<1$ \\
\hline \multicolumn{3}{|c|}{ Maximum } & 0.9 & 53.0 & 2.7 & 13.0 & 92.0 & 303.0 & 80.0 & 2450 & 29.0 & 35.0 & 1520.0 & 478.0 & 8.0 \\
\hline
\end{tabular}

The values of the natural concentrations of metals (background) reported in this study were drawn from published literature over the past 30 years. In addition to studies carried out in the study area, were also considered previously acquired data at Ilha Grande Bay region, such as Ribeira Bay and Praia do Sul Biological Reserve, considered as reference areas (Lacerda et al., 1982; Lacerda, 1983; DePaula and Mozeto, 2001). These previous works have included studies on metals in cores and bottom surface sediments from the Ilha Grande Bay.

Average values of essential trace elemental concentrations (As, $\mathrm{Cr}, \mathrm{Cu}, \mathrm{Mn}, \mathrm{Zn}, \mathrm{Al}$ and $\mathrm{Fe}$ ) in the analyzed samples were compared with values considered natural obtained through core analyses and in surface sediments in areas under reduced anthropogenic influence, such as Praia do Sul and Ribeira Bay, adjacent to Ilha Grande Bay (Silva-Filho et al., 1996; DePaula and Mozeto, 2001; Wasserman et al., 2001; Marques Jr. et al., 2006; Gomes et al., 2009). This comparison allowed to verify that in the Western sector of Sepetiba Bay these elements concentrations were above the local background values.

The average values of $\mathrm{Cr}(46.98 \mu \mathrm{g} / \mathrm{g}), \mathrm{Cu}(62.59 \mu \mathrm{g} / \mathrm{g})$, $\mathrm{Mn}(679.7 \mu \mathrm{g} / \mathrm{g})$ and $\mathrm{Zn}(184.82 \mu \mathrm{g} / \mathrm{g})$ in the study area showed a marked difference compared to that obtained in Praia do Sul Biological Reserve (Ilha Grande Bay) according to DePaula and Mozeto (2001). The reported values range from 2.5 to $2.7 \mu \mathrm{g} / \mathrm{g}$ for $\mathrm{Cr} ; 11$ to $17 \mu \mathrm{g} / \mathrm{g}$ for $\mathrm{Cu} ; 60$ to $325 \mu \mathrm{g} / \mathrm{g}$ for Mn and; 42.5 to $156 \mu \mathrm{g} / \mathrm{g}$ for $\mathrm{Zn}$. Silva-Filho et al. (1996) reported levels close to $15.75 \mu \mathrm{g} / \mathrm{g}$ for $\mathrm{Zn}$, at the same region.

The concentration of metals in areas under strong human influence is orders of magnitude higher than in those less affected by anthropic activities, as Ribeira Bay or Praia do Sul, in Ilha Grande, as we observe in the profiles studied by Silva-Filho et al. (1996) and Patchineelam et al. (2011). These authors reported metal results in a core, and the average concentration of $\mathrm{Zn}$ in sediments of the region of Praia do Sul, in a depth from 19 to $30 \mathrm{~cm}$, was 15.75 $\mu \mathrm{g} / \mathrm{g}$ (Silva-Filho et al., 1996), while in a similar depth (10 to $32 \mathrm{~cm}$ ) in the region of Saco da Marambaia (Sepetiba Bay) the value was about $500 \mu \mathrm{g} / \mathrm{g}$ (Patchineelam et al., 2011). Barcellos et al. (1991) found natural values in the pre-industrial period for $\mathrm{Zn}$ of $2.6 \mu \mathrm{g} / \mathrm{g}$, in Saco do Engenho (Sepetiba Bay). These values are much lower than those reported in this research $(184.82 \mu \mathrm{g} / \mathrm{g})$.

The study of Magalhães and Pfeiffer (1995) points out that the area where a high volume of ore tailings from the discontinued mining company Cia Mercantil Ingá are released, also as Ilha do Diabo (Devil's Island), functions as a source of metallic waste for Sepetiba Bay.

In the region of Saco do Engenho, at a depth of 20 to $28 \mathrm{~cm}$ below the top of sediment cores, these authors obtained values for As between 260 and $360 \mu \mathrm{g} / \mathrm{g}$. These values indicate that the shutdown mining company $\mathrm{Cia}$ Mercantil Ingá greatly contributes to the enrichment of metals in Sepetiba Bay, considering the natural values of $<5 \mu \mathrm{g} / \mathrm{g}$ for As obtained by Wasserman et al. (2001) for this bay.

Chromium, $\mathrm{Cu}, \mathrm{Mn}, \mathrm{Zn}$, and Fe presented average concentrations in the study area, above the values reported by other studies in Sepetiba and Ilha Grande bays. In the Western sector of Sepetiba Bay, the average concentration of $\mathrm{Cr}(46.98 \mu \mathrm{g} / \mathrm{g})$ was higher than those obtained by Lacerda $(1983 ; 30.9 \mu \mathrm{g} / \mathrm{g})$ and Lacerda et al. (1982; 8.48 $\mu \mathrm{g} / \mathrm{g})$ in Ribeira Bay, a less anthropized area.

These authors reported Cr concentrations of $25.2 \mu \mathrm{g} / \mathrm{g}$ and $7.7 \mu \mathrm{g} / \mathrm{g}$, respectively. Lacerda et al. (1987) observed $\mathrm{Cu}$ values of $38.8 \mu \mathrm{g} / \mathrm{g}$ for Sepetiba Bay, Gomes et al. (2009) of $31.9 \mu \mathrm{g} / \mathrm{g}$ for the Eastern sector of Sepetiba Bay and Freret-Meurer et al. (2010), of $11.64 \mu \mathrm{g} / \mathrm{g}$ for Ribeira Bay. The values reported for $\mathrm{Cu}$ in these studies are lower than that recorded in the Western Sector do Sepetiba Bay (in those survey, $62 \mu \mathrm{g} / \mathrm{g}$ ). 
The average concentration of $\mathrm{Mn}(679.7 \mu \mathrm{g} / \mathrm{g})$ in the study area also surpassed the values reported by: Lacerda (1983) of $123 \mu \mathrm{g} / \mathrm{g}$ for Ribeira Bay; Lacerda, et al. (1987) of $301 \mu \mathrm{g} / \mathrm{g}$ for Sepetiba Bay; Patchineelam et al. (1987) of $453 \mu \mathrm{g} / \mathrm{g}$ to Coroa Grande, in Sepetiba Bay; Barcellos et al. (1997) of $421 \mu \mathrm{g} / \mathrm{g}$ to the Eastern sector of Sepetiba Bay; Cardoso et al.(2001) of $469 \mu \mathrm{g} / \mathrm{g}$ for Ribeira Bay; DePaula and Mozeto (2001) from <96 $\mu \mathrm{g} / \mathrm{g}$ to $279 \mu \mathrm{g} / \mathrm{g}$ to Praia do Sul in Ilha Grande; Gomes et al. (2009) of 595
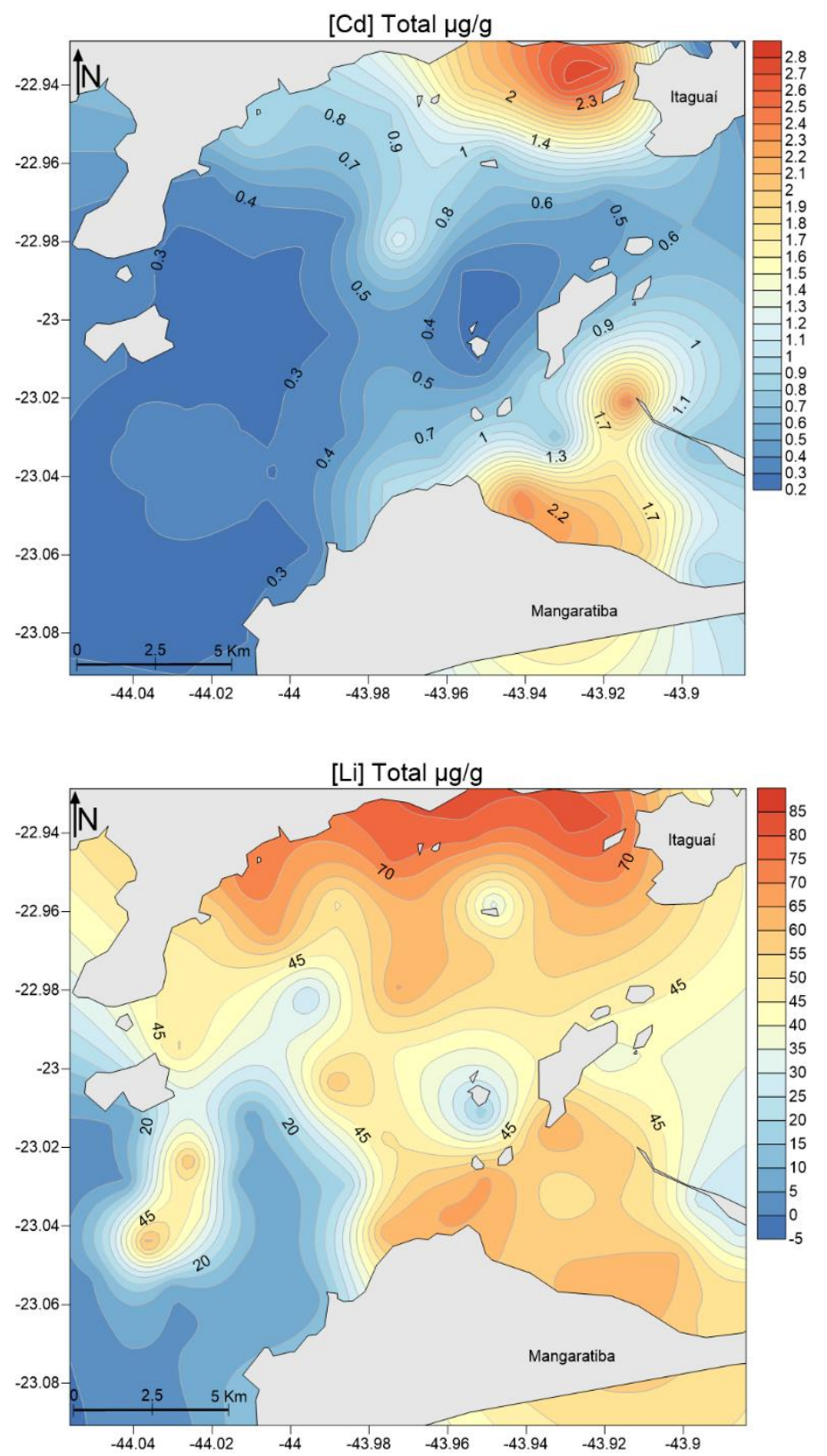

$\mu \mathrm{g} / \mathrm{g}$ at the Eastern sector of Sepetiba Bay and; FreretMeurer et al. (2010) of $283.26 \mu \mathrm{g} / \mathrm{g}$ in Ribeira Bay.

The average concentration of $\mathrm{Zn}(184.82 \mu \mathrm{g} / \mathrm{g})$ recorded in the study area also exceeds the levels obtained in Ribeira Bay (Lacerda et al., 1982; Lacerda, 1983; Cardoso et al., 2001; Freret-Meureret al., 2010).

The average concentration of $\mathrm{Fe}(3.2 \%)$ is also above the values found in Coroa Grande $(2.79 \%)$ and Ribeira Bay $(2.42 \%)$ as noticed by Patchineelam et al. (1987) and Freret-Meurer et al. (2010), respectively
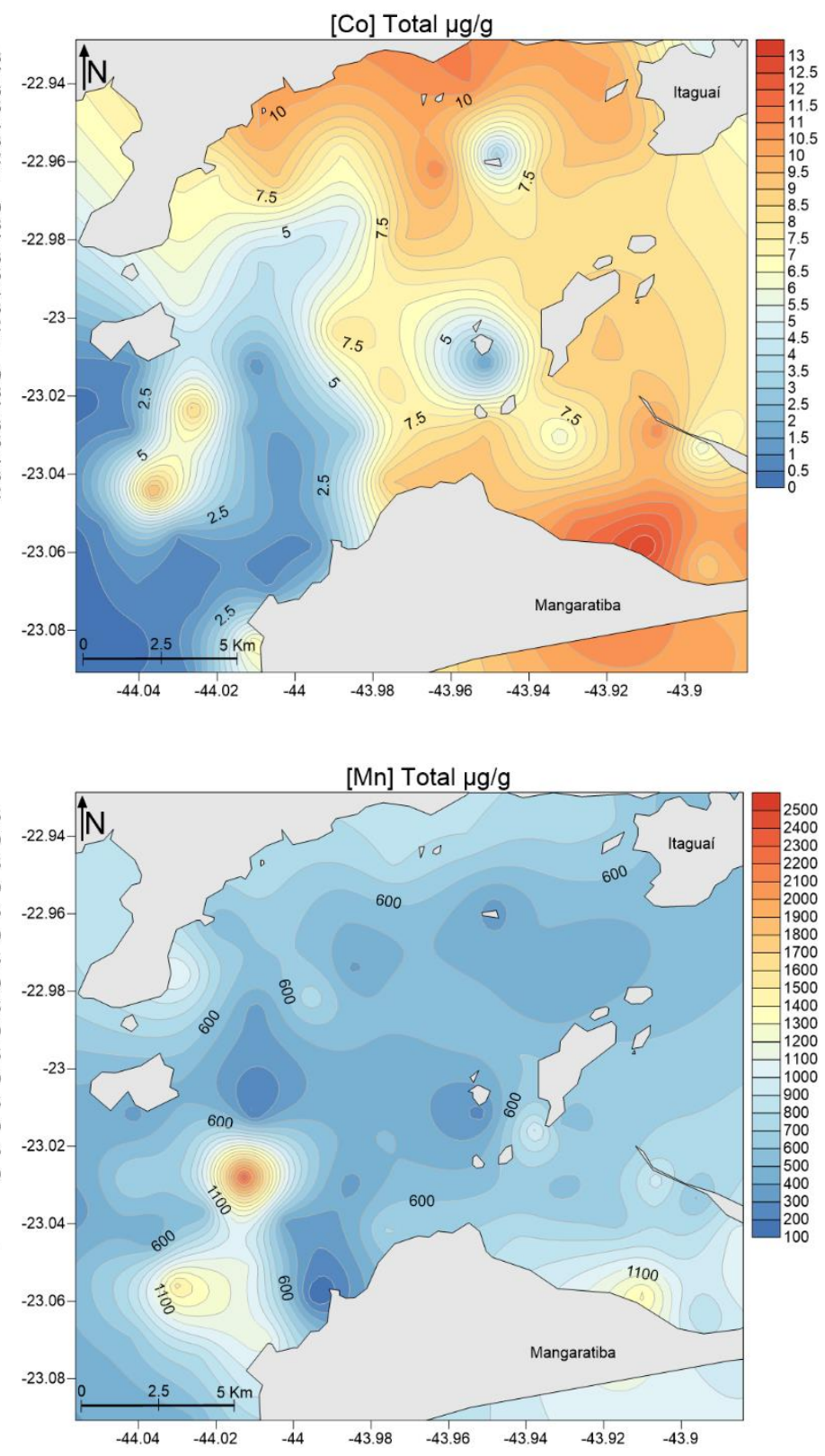

Fig. 3. Map of distribution of the total trace element concentration of $\mathrm{Cd}, \mathrm{Co}, \mathrm{Li}$ and $\mathrm{Mn}$.

\subsection{Non-essential trace elements (Ag, Cd, Co, Li, Ni, Pb, Sr, Hg)}

In the study area, $\mathrm{Ag}$ (Appendix $3 \mathrm{~A}$ ) concentrations varied between $<0.3 \mu \mathrm{g} / \mathrm{g}$ and $1 \mu \mathrm{g} / \mathrm{g}$ (average $0.4 \pm 0.16$ $\mu \mathrm{g} / \mathrm{g}$; Table 1). Concentrations of $\mathrm{Cd}$ and $\mathrm{Co}$ (Appendix 3 $\mathrm{B}$ and $\mathrm{C}$ ) ranged from $<0.3 \mu \mathrm{g} / \mathrm{g}$ to $2.7 \mu \mathrm{g} / \mathrm{g}$ and $<1 \mu \mathrm{g} / \mathrm{g}$ to $13 \mu \mathrm{g} / \mathrm{g}$, respectively (averages of $0.76 \pm 0.61 \mu \mathrm{g} / \mathrm{g}$ and $6.65 \pm 3.6 \mu \mathrm{g} / \mathrm{g}$, respectively; Table 1). Lithium (Appendix 
$3 \mathrm{D}), \mathrm{Ni}$ and $\mathrm{Pb}$ (Appendix $4 \mathrm{~A}$ and $\mathrm{B}$ ) concentrations oscillated between $4 \mu \mathrm{g} / \mathrm{g}$ to $80 \mu \mathrm{g} / \mathrm{g},<1 \mu \mathrm{g} / \mathrm{g}$ to $29 \mu \mathrm{g} / \mathrm{g}$ and $5 \mu \mathrm{g} / \mathrm{g}$ to $35 \mu \mathrm{g} / \mathrm{g}$, respectively (averages of $43.29 \pm 23.91 \mu \mathrm{g} / \mathrm{g}, 16.65 \pm 8.23 \mu \mathrm{g} / \mathrm{g}$ and $20.08 \pm 6 \mu \mathrm{g} / \mathrm{g}$, respectively; Table 1). Sr and $\mathrm{Hg}$ (Appendix $4 \mathrm{C}$ and D) reached concentrations of $152 \mu \mathrm{g} / \mathrm{g}$ to $1520 \mu \mathrm{g} / \mathrm{g}$ and $<1.0$ $\mu \mathrm{g} / \mathrm{g}$ to $8.0 \mu \mathrm{g} / \mathrm{g}$ (averages of $389.64 \pm 287.05 \mu \mathrm{g} / \mathrm{g}$ and $1.11 \pm 0.86 \mu \mathrm{g} / \mathrm{g}$, respectively; Table 1$)$.

Station S02 presented the highest level of Cd $(2.7 \mu \mathrm{g} / \mathrm{g})$ and $\mathrm{Li}(80 \mu \mathrm{g} / \mathrm{g})$. Stations S07, S20, S30, S38 showed higher concentrations of $\mathrm{Ag}(1 \mu \mathrm{g} / \mathrm{g})$, Pb $(35 \mu \mathrm{g} / \mathrm{g})$, Co (13 $\mu \mathrm{g} / \mathrm{g})$ and $\mathrm{Ni}(29 \mu \mathrm{g} / \mathrm{g})$, respectively. Highest levels of Sr and $\mathrm{Hg}$ were found, in the stations S56 $(1520 \mu \mathrm{g} / \mathrm{g})$ and S21 $(8 \mu \mathrm{g} / \mathrm{g})$, respectively.
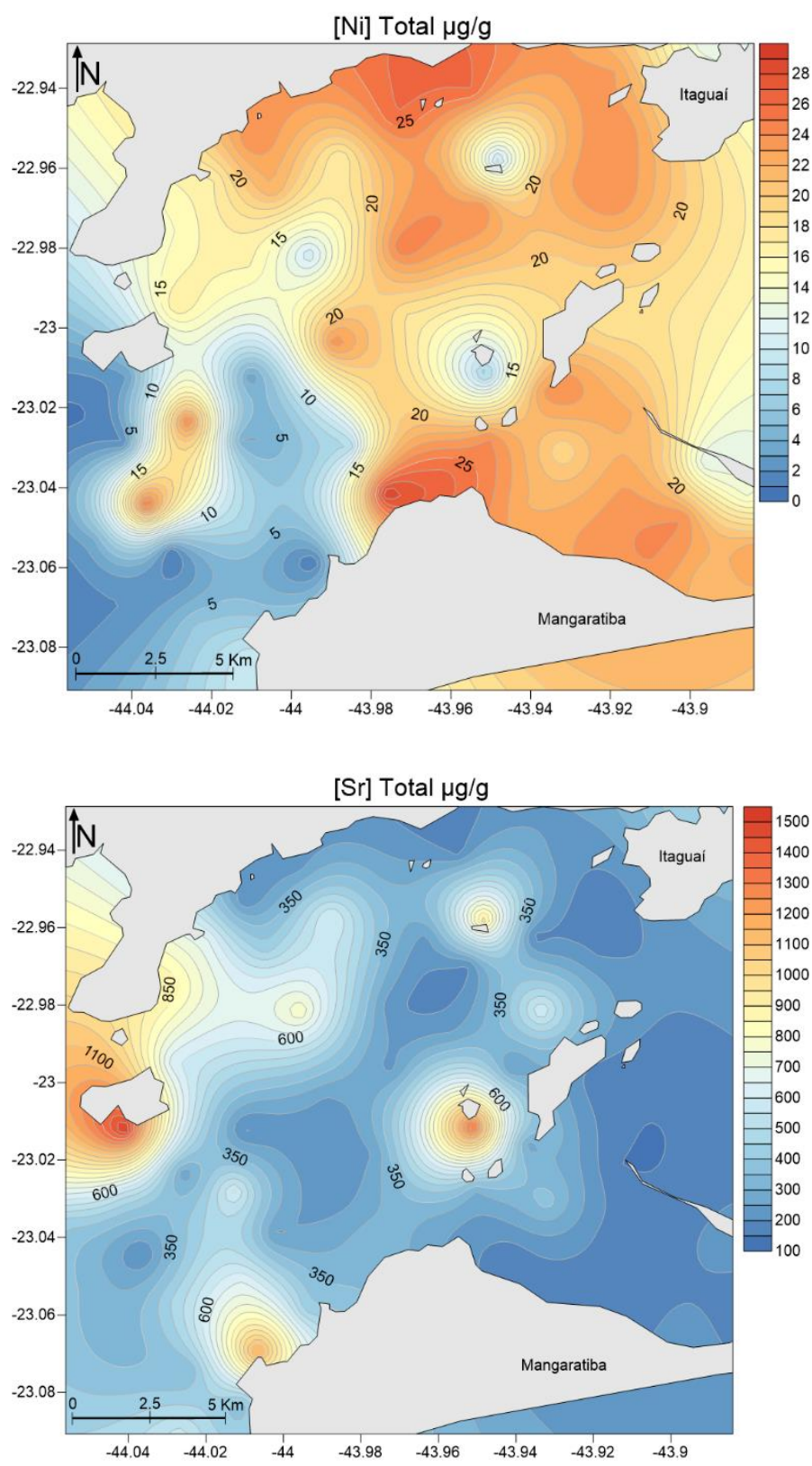

The average concentrations of $\mathrm{Ag}(0.4 \mu \mathrm{g} / \mathrm{g}), \mathrm{Cd}(0.76$ $\mu \mathrm{g} / \mathrm{g}), \mathrm{Co}(6.65 \mu \mathrm{g} / \mathrm{g}), \mathrm{Hg}(1.11 \mu \mathrm{g} / \mathrm{g}), \mathrm{Li}(43.29 \mu \mathrm{g} / \mathrm{g}), \mathrm{Ni}$ $(16.65 \mu \mathrm{g} / \mathrm{g}), \mathrm{Pb}(20.08 \mu \mathrm{g} / \mathrm{g})$ and $\mathrm{Sr}(389.64 \mu \mathrm{g} / \mathrm{g})$, in surface bottom sediments of the Western Sector of Sepetiba Bay, were above the local natural and global levels as reported by Rocha et al. (2010).

Marques Jr. et al. (2006) reported for the pre-industrial period, at cores collected in the region of Coroa Grande (Sepetiba Bay), Cd levels $<0.2 \mu \mathrm{g} / \mathrm{g}$. These authors also recorded Cd values $<0.34 \mu \mathrm{g} / \mathrm{g}$ in the region between São Francisco Canal and the Guandu River. Gomes et al. (2009) also reported similar values for the Ribeira Bay region $(0.22 \mu \mathrm{g} / \mathrm{g})$.
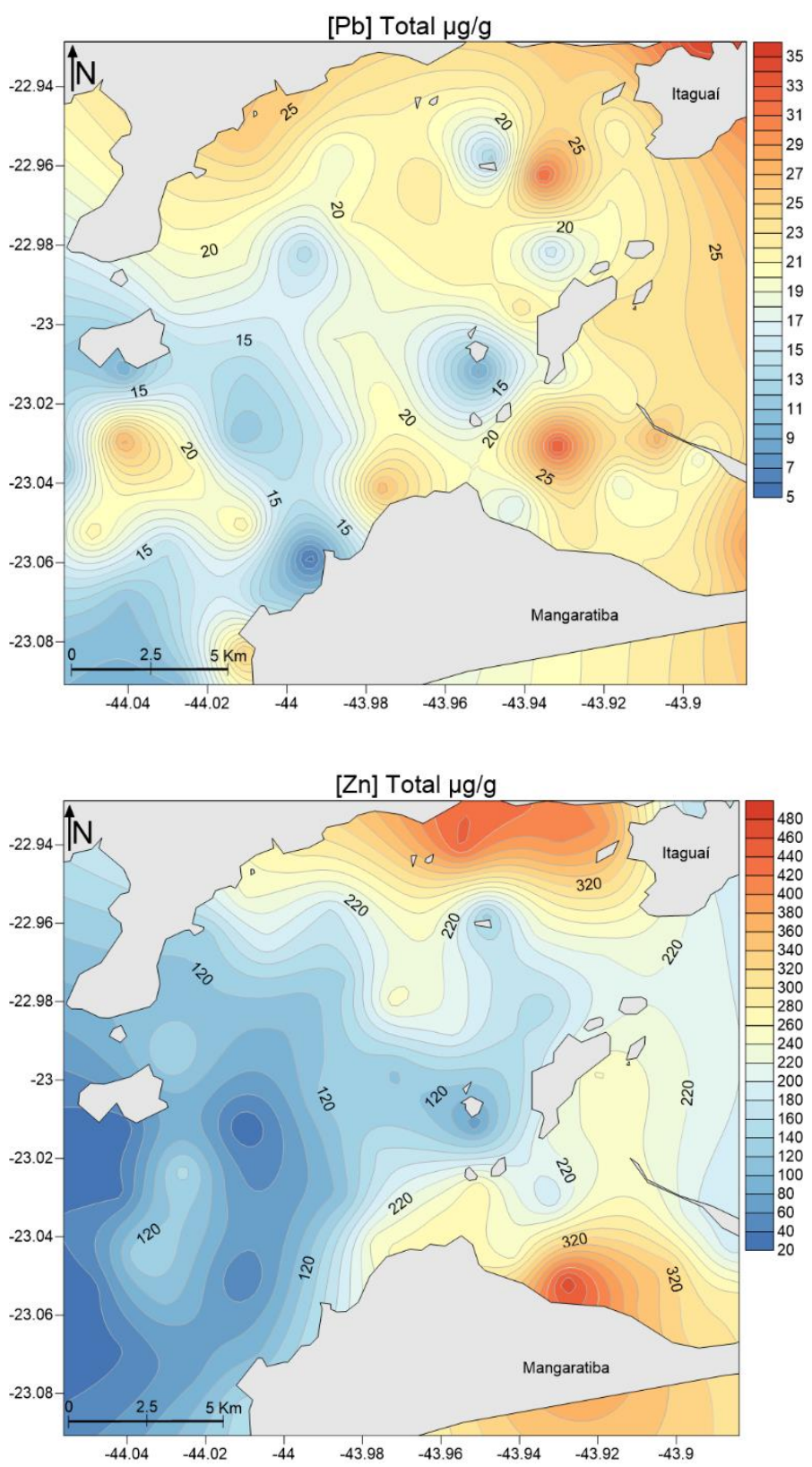

Fig. 4. Map of distribution of the total trace element concentration of $\mathrm{Ni}, \mathrm{Pb}, \mathrm{Sr}$ and $\mathrm{Zn}$. 
The average values of Co concentration were above the natural values reported by Wasserman et al. (2001) in a core obtained in Enseada das Garças $(<3 \mu \mathrm{g} / \mathrm{g})$ and Coroa Grande $(1.25 \mu \mathrm{g} / \mathrm{g})$.

The average of $\mathrm{Pb}$ concentrations was within the natural limits presented by DePaula and Mozeto (2001) in a core collected in Ribeira Bay (12.5 to $50 \mu \mathrm{g} / \mathrm{g}$ ), although it exceeded the world reference values $(13.5 \mu \mathrm{g} / \mathrm{g})$.

We have not found background values in sediments for $\mathrm{Ag}, \mathrm{Hg}, \mathrm{Li}, \mathrm{Ni}$ and $\mathrm{Sr}$ but, through comparison with global references, it was found that the average concentrations obtained in this study for these metals exceeded the permissible limits.

The comparison of this result with the averages of total non-essential metal concentrations obtained in bottom surface sediments reported by other authors confirm their enrichment in the western sector of Sepetiba Bay.

The average of $\mathrm{Ag}(0.4 \mu \mathrm{g} / \mathrm{g}), \mathrm{Cd}(0.76 \mu \mathrm{g} / \mathrm{g})$ and Co $(6.65 \mu \mathrm{g} / \mathrm{g})$ concentrations were above the values reported by Freret-Meurer et al. (2010) $(0.2 \mu \mathrm{g} / \mathrm{g}, 0.2 \mu \mathrm{g} / \mathrm{g}$ and 5,76 $\mu \mathrm{g} / \mathrm{g}$, respectively). These authors, as well as Lacerda et al. (1982) reported natural values for $\mathrm{Ni}(13.02 \mu \mathrm{g} / \mathrm{g}$ and 5.9 $\mu \mathrm{g} / \mathrm{g}$, respectively) and $\mathrm{Pb}(16.48 \mu \mathrm{g} / \mathrm{g}$ and $8.33 \mu \mathrm{g} / \mathrm{g}$, respectively) in Ribeira Bay region, at lower levels than those obtained in this study $(16.65 \mu \mathrm{g} / \mathrm{g}$ and $20.08 \mu \mathrm{g} / \mathrm{g}$, respectively).

Average levels of $\mathrm{Sr}$ found in this study (average of $392.9 \mathrm{ug} / \mathrm{g}$ ) also exceeded the values obtained by Patchineelam et al. (1987) for Coroa Grande region (201.5 $\mu \mathrm{g} / \mathrm{g})$, Cardoso et al. (2001) for Ribeira Bay area $(163 \mu \mathrm{g} / \mathrm{g})$ and Gomes et al. (2009) for the East sector of Sepetiba Bay $(78 \mu \mathrm{g} / \mathrm{g})$. The average content of $\mathrm{Hg}$ was above the value reported by Cardoso et al. (2001) for Ribeira Bay (0.028 $\mu \mathrm{g} / \mathrm{g})$, as well as the average concentration of $\mathrm{Li}$ that surpassed the worldwide background $(40.5 \mu \mathrm{g} / \mathrm{g})$.

\subsection{Distribution of trace elemental concentrations}

In each map (Figs. 2-5), the regions in light pink encompass the highest concentrations of the analyzed elements. These maps evidence that the Saco da Marambaia region presents higher concentrations of $\mathrm{Cd}$, $\mathrm{Co}, \mathrm{Cr}, \mathrm{Mn}, \mathrm{Pb}$ and $\mathrm{Zn}$. On the other hand, similarly to the previous region, the northern area presents the highest levels of $\mathrm{Cd}$, Co and $\mathrm{Zn}$ and also encompasses the highest concentrations of $\mathrm{Ag}$, As, $\mathrm{Li}$ and $\mathrm{Ni}$. The concentrations of these elements are also higher than those reported by Pinto et al. (2019), for unpolluted sediments of Sepetiba Bay, namely for As, Cd, Co, Cu, Mn, Cu, Ni, Pb, Sr and Zn.

The comparison of the distribution maps of the concentration of the trace elements with the granulometric map of Sepetiba Bay developed by Pereira (1998) points out that there is some relationship between metal concentrations versus grain size. Most of the metals were adsorbed on grains of smaller size such as clay, silt and very fine sand. According to Passos (2005), a larger surface area of the sediment grain has greater efficiency in metals adsorption, that is, grains of smaller sizes concentrate more metals.

\section{Conclusion}

Results obtained in this work evidence that there is an enrichment of trace elements in the Western Sector of Sepetiba Bay. The total concentrations of $\mathrm{Ag}(0.40 \mu \mathrm{g} / \mathrm{g})$, $\mathrm{Cd}(0.76 \mu \mathrm{g} / \mathrm{g}), \mathrm{Cu}(62.59 \mu \mathrm{g} / \mathrm{g}), \mathrm{Li}(43.29 \mu \mathrm{g} / \mathrm{g}), \mathrm{Ni}(16.65$ $\mu \mathrm{g} / \mathrm{g}), \mathrm{Pb}(20.08 \mu \mathrm{g} / \mathrm{g}), \mathrm{Sr}(389.64 \mu \mathrm{g} / \mathrm{g})$ and $\mathrm{Zn}(184.2$ $\mu \mathrm{g} / \mathrm{g})$ exceeded the recommended limits by the legislation, in addition to being above the natural values found in Ribeira Bay (RJ), considered the control region, due to its low anthropic influence. This may be a consequence of human activities, related to the harbors, industries, as well as dredging, which resuspend the sediments and contribute to the reintroduction of metals in the water column, besides the permanence of the metal waste ore from the deactivated mining company Ingá. Thus, environmental monitoring is necessary in this area, since it is a region of high biological, social and economic importance.

\section{Acknowledgments}

We would like to thank the Coordenação de Aperfeiçoamento de Pessoal de Nível Superior (CAPES) for financing the project Fine Sediments into estuaries and PC: formation and dynamics of silts deposits (AUXPE Ciências do Mar 530/2010) and for the masters fellowship granted to the first author; the Fundação de Amparo à Pesquisa do Estado do Rio de Janeiro (FAPERJ) for financing the projects "Interaction between the bays of Sepetiba and Ilha Grande: circulation and sedimentation patterns and the anthropic influence" (E-26/110.290/2010) and "Interactions between Sepetiba bay and the nearby continental shelf: circulation patterns and sediment transport" (E26/110.590/2011). Special thanks to Margareth S. Navarro and Jacinta Enzweiler, from Analytical Geochemistry Laboratory (UNICAMP); to the trainees of Geological Samples Preparation Laboratory (FGEL, UERJ) and to the colleagues from Programa de Pos Graduação em Oceanografia who participated in the sampling campaigns.

\section{References}

Barcellos, C., Lacerda, L.D., Ceradini, S. 1997. Sediment origin and budget in Sepetiba Bay (Brazil) - an approach based on multielemental analysis. Environmental Geology 32 (3), 203-209.

Barcellos, C. 1995. Geodinâmica de cádmio e zinco na Baía de Sepetiba. PhD Thesis Universidade Federal Fluminense, Rio de Janeiro, $148 \mathrm{p}$.

Barcellos, C., Rezende, C. E., Pfeiffer, W.C., 1991. Zinc and Cadmium production and pollution in a Brazilian coastal 
region. Marine Pollution Bulletin 22 (11), 558-561. https://doi.org/10.1016/0025-326X(91)90896-Z

Canadian Sediment Quality Guidelines for the Protection of Aquatic Life. Environmental Canada 1999. Canadian Environmental Quality Guidelines - Summary Tables. $<$ http://www.ec.gc.ca>, updated in 2002

Cardoso, Ricardo S., Meireis, Felipe, Mattos, Gustavo, 2019. Crustaceans composition in sandy beaches of Sepetiba Bay, Rio de Janeiro, Brazil. Check List 7 (6), 778-781, http://dx.doi.org/10.15560/11024.

Cardoso, A.G.A., Boaventura, G.R., Silva Filho, E.V., Brod, J.A., 2001. Metal Distribution in Sediments from the Ribeira Bay, Rio de Janeiro - Brazil. Journal of the Brazilian $\begin{array}{llll}\text { Chemical } & \text { Society } & 12 & \text { (6), }\end{array}$ http://dx.doi.org/10.1590/S0103-50532001000600013

CONAMA Resolution 454/2012. Resolução CONAMA No 454/2012 - "Estabelece as diretrizes gerais e os procedimentos referenciais para o gerenciamento do material a ser dragado em águas sob jurisdição nacional." Data da legislação: 01/11/2012 - Publicação DOU, de 08/11/2012, Seção 1, pág. 66. Status: Revoga as Resoluções $\mathrm{n}^{\circ} 344$ de 2004 e $\mathrm{n}^{\circ} 421$ de 2010. http://www2.mma.gov.br/port/conama/ legiabre.cfm?codlegi=693

Cunha, B.C.A., Rocha, D., Geraldes, M.C., Pereira, S.D., Almeida, A.C., 2009. Pb isotopic signatures in sediments of a sub-tropical coastal lagoon: Anthropogenic sources for metal contamination in the Sepetiba Bay (SE-Brazil). Journal of Coastal Research 56, 797-801.

Cunha, C.L.N., Rosman, P.C.C., Ferreira, A.P., Monteiro, T C.N., 2006. Hydrodynamics and water quality models applied to Sepetiba Bay. Continental Shelf Research 26, 1940-1953.

DePaula, F.C.F., Mozeto, A.A., 2001. Biogeochemical evolution of trace elements in a pristine watershed in the Brazilian southeastern coastal region. Applied Geochemistry 16, 1139-1151.

Florida Sediment Quality Assessment Guidelines (Florida SQAG'S), https://floridadep.gov/dear/watershedmonitoring-section/content/sediment-guidelines.

Freret-Meurer, N.V., Andreata, J.V., Meurer, B.C., Manzano, F.V., Baptista, M.G.S., Teixeira, D.E., Longo, M.M., 2010. Spatial distribution of metals in sediments of the Ribeira Bay, Angra dos Reis, Rio de Janeiro, Brazil. Marine Pollution Bulletin 60, 627-629. https://doi.org/10.1016/j.marpolbul. 2010.01.023

Gomes, F.C., Godoy, J.M., Godoy, M.L.D.P., Carvalho, Z.L., Lopes, R.T., Sanchez-Cabeza, J.A., Lacerda, L.D., Wasserman, J.C., 2009. Metal concentrations, fluxes, inventories and chronologies in sediments from Sepetiba and Ribeira Bays: A comparative study. Marine Pollution Bulletin 59, 123-133. https://doi.org/10.1016/j.marpolbul. 2009.03.015

Guilherme, L.R.G., Marques, J.J., Pierangeli, M. A. P., Zuliani, D.Q., Campos, M.L., Marchi, G., 2005. Elementos-traço em solos e sistemas aquáticos. Tópicos Ci. Solo, Viçosa, 4, 345-390.

Lacerda, L.D., Molisani, M.M., 2006. Three decades of Cd and Zn contamination in Sepetiba Bay, SE Brazil: Evidence from the mangrove oyster Crassostrea rhizophorae. Marine Pollution Bulletin52, 969-987. https://doi.org/10.1016/j.marpolbul. 2006.04.007

Lacerda, L.D., Pfeiffer, W.C., Fiszman, M., 1987. Heavy metal distribution, availability and fate in Sepetiba Bay, SE Brazil.
RESEARCH PAPER

The Science of The Total Environment 65, 163-173. https://doi.org/10.1016/0048-9697(87)90169-0

Lacerda, L.D. de, Pfeiffer, C.F., Fiszman, M.,1982. Níveis naturais de metais pesados ems edimentos marinhos da Baía da Ribeira, Angra dos Reis. Ciência e Cultura 34 (7), 921-924.

Lacerda, L.D. de, 1983. Aplicação da metodologia de abordagem pelos parâmetros críticos no estudo da poluição por metais pesados na Baía de Sepetiba, Rio de Janeiro. PhD Thesis, Universidade Federal do Rio de Janeiro, Rio de Janeiro, 136 p.

Magalhães, V.F., Pfeiffer, W.C.,1995. Arsenic concentration in sediments near a metallurgical plant (Sepetiba Bay, Rio de Janeiro, Brazil). Journal of Geochemical Exploration 52 (12), $175-181$. https://doi.org/10.1016/03756742(94)00025-7

Marques Jr., A.N., Monna, F., Silva Filho, E.V., Fernex, F.E., Simões Filho, F.F.L., 2006. Apparent discrepancy in contamination history of a sub-tropical estuary evaluated through ${ }^{210} \mathrm{~Pb}$ profile and chronostratigraphical markers. Marine Pollution Bulletin 52, 532-539. https://doi.org/10.1016/j.marpolbul.2005.09.048

Molisani, M.M., Marins, R.V., Machado, W., Paraquetti, H.H.M., Bidone, E.D., Lacerda, L.D., 2004. Environmental changes in Sepetiba Bay, SE Brasil. Regional Environmental Change 4, 17-27.

NOAA, United States National Oceanic and Atmospheric Administration, 1999. Sediment Quality Guidelines developed for the National Status and Trends Program, p. 1-12.

PACS, Instituto de Politicas Alternativas para o Cone Sul, 2012. Companhia Siderúrgica do Atlântico - TKCSA: Impactos e Irregularidades na Zona Oeste do Rio de Janeiro. $3^{\mathrm{a}}$ Edição, Rio de Janeiro, PACS, 80 p.

Passos, E. de A. 2005. Distribuição de sulfeto volatilizado em meio ácido e metais pesados em sedimentos do estuário do rio Sergipe. MsD Thesis, Universidade Federal de Sergipe. Sergipe, $141 \mathrm{p}$.

Patchineelam, S.M., Sanders, C.J., Smoak, J.M., Zem, R.C., Oliveira, G., Patchineelam, S.R., 2011. A historical evaluation of anthropogenic impact in coastal ecosystems by geochemical signatures. Journal of the Brazilian Chemical Society 22 (1), 120-125.

Patchineelam, S.R., Bezerra, H.C., Souza, S.R.A., Pires, V.S., Azevedo, F.V.,1987. Composição química de sedimentos superficiais de manguezais da Baía de Sepetiba, Rio de Janeiro, Brasil. Geochimica Brasiliensis 1 (2), 177-186.

Patterson C., Settle D., Glover, B., 1976. Analysis of lead in polluted coastal seawater. Marine Chemistry 4, 305-319.

Pellegatti, F. 2000. Determinação de metais pesados e outros elementos em sedimentos da Bala de Sepetiba (RJ), por ativação neutrônica. MsD Thesis, Universidade de São Paulo, São Paulo, Brazil, 119 p.

Pereira, S.D. 1998. Influência da variação relativa do nível do mar no Manguezal de Guaratiba-Baia de Sepetiba-RJ. 1998. PhD Thesis, Universidade Federal do Rio Grande do Sul, 152 p.

Pinto, A.F.S., Ramalho, J.C.M., Borghi, L., Carelli, T.G., Plantz, J.B., Pereira, E., Terroso, D., Santos, W.H., Geraldes, M.C., Rocha, F., Rodrigues, M.A.C., Laut, L., Martins, M.V.A., 2019. Background concentrations of chemical elements in Sepetiba Bay (SE Brazil). Journal of Sedimentary Environments 4 (1), 108-123. http://dx.doi.org/10.12957/ jse.2019.40992 
Rio de Janeiro (Estado), 1998. Secretaria do Estado do Meio Ambiente do Rio de Janeiro. .Macroplano de gestão e Saneamento Ambiental da bacia da Baía de Sepetiba. Volume 1: Diagnóstico ambiental. Rio de Janeiro. SEMA, Relatório final, $250 \mathrm{p}$.

Rocha, D.S., Cunha, B.C.A., Geraldes, M.C., Pereira, S.D, and Almeida, A.C. 2010 Metais pesados em sedimentos da baía de Sepetiba, RJ: implicações sobre fontes e dinâmica da distribuição pelas correntes de maré. Geochimica Brasiliensis 24, 63-70.

Santos, A.L.B., 2007. Sedimento e comunidades de peixes como indicadores da qualidade Ambiental em praias insulares e continentais na Baía de Sepetiba, RJ. Monography,

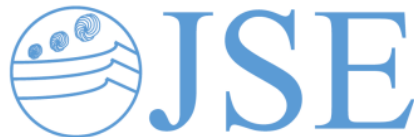

Universidade Federal Rural do Rio de Janeiro, Rio de Janeiro, $29 \mathrm{p}$.

Silva-Filho, E.V., Wasserman, J.C., Lacerda, L.D., 1996. History heavy metals inputs recorded on sediment cores from a remote environment. In: International Conference Pollution Process in Coastal Environments, Mar Del Plata, p. 182-186.

Turekian, K., Wedepohl, K.H.,1961. Distribution of the elements in some major units of the earth's crust. Geological Society of America Bulletin 72, 175-192.

Wasserman, J.C., Figueiredo, A.M.G., Pellegatti, F., Silva-Filho, E.V., 2001. Elemental composition of sediment cores from a mangrove environment using neutron activation analysis. Journal of Geochemical Exploration 72, 129-146. http://dx.doi.org/10.1016/S0375-6742(01)00158- 
As $\left(\mu \mathrm{g} \mathrm{g}^{-1}\right)$

60

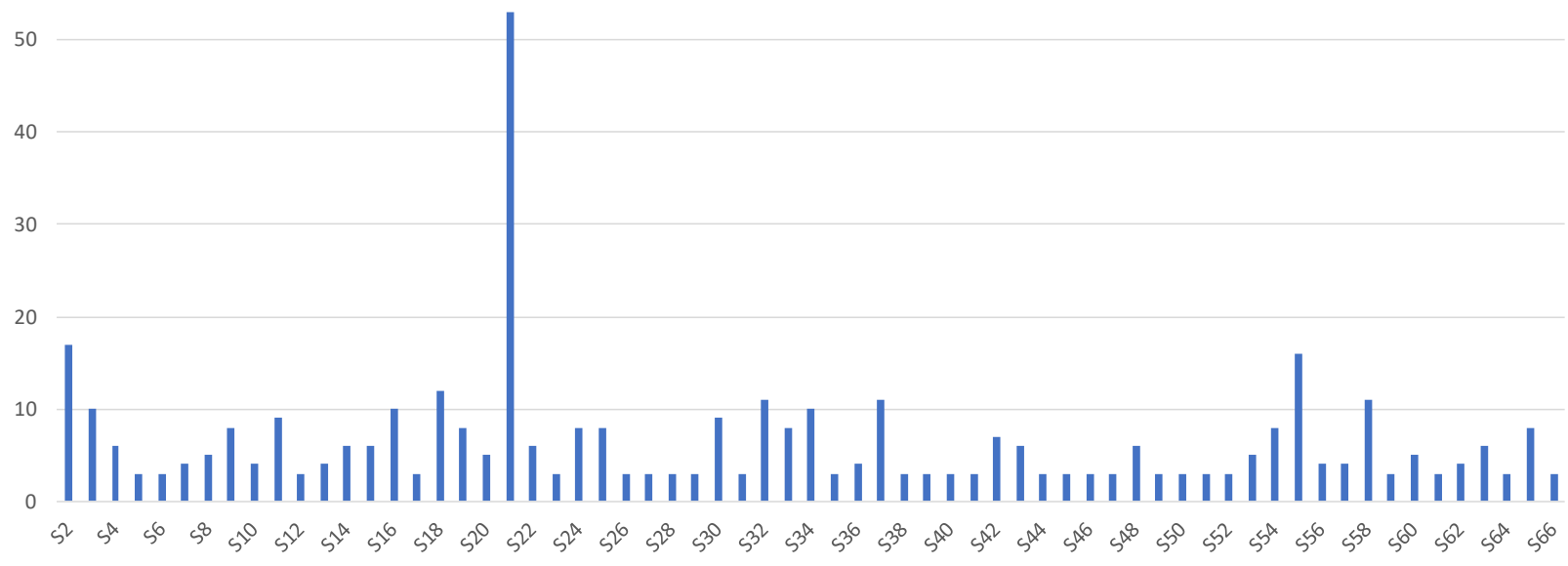

$\mathrm{Cu}\left(\mu \mathrm{g} \mathrm{g}^{-1}\right)$

350
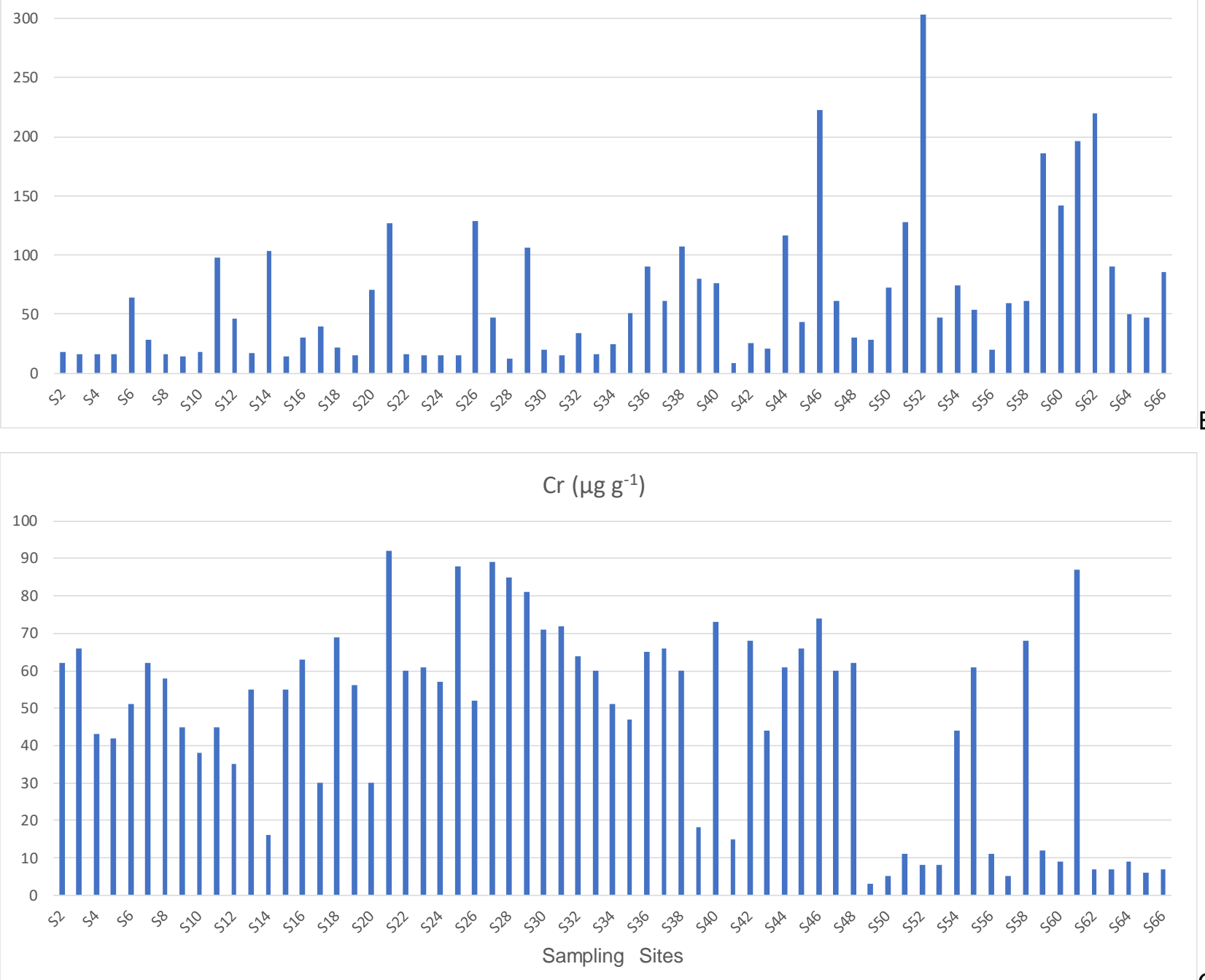

Appendix 1. Concentration of essential elements by station. 

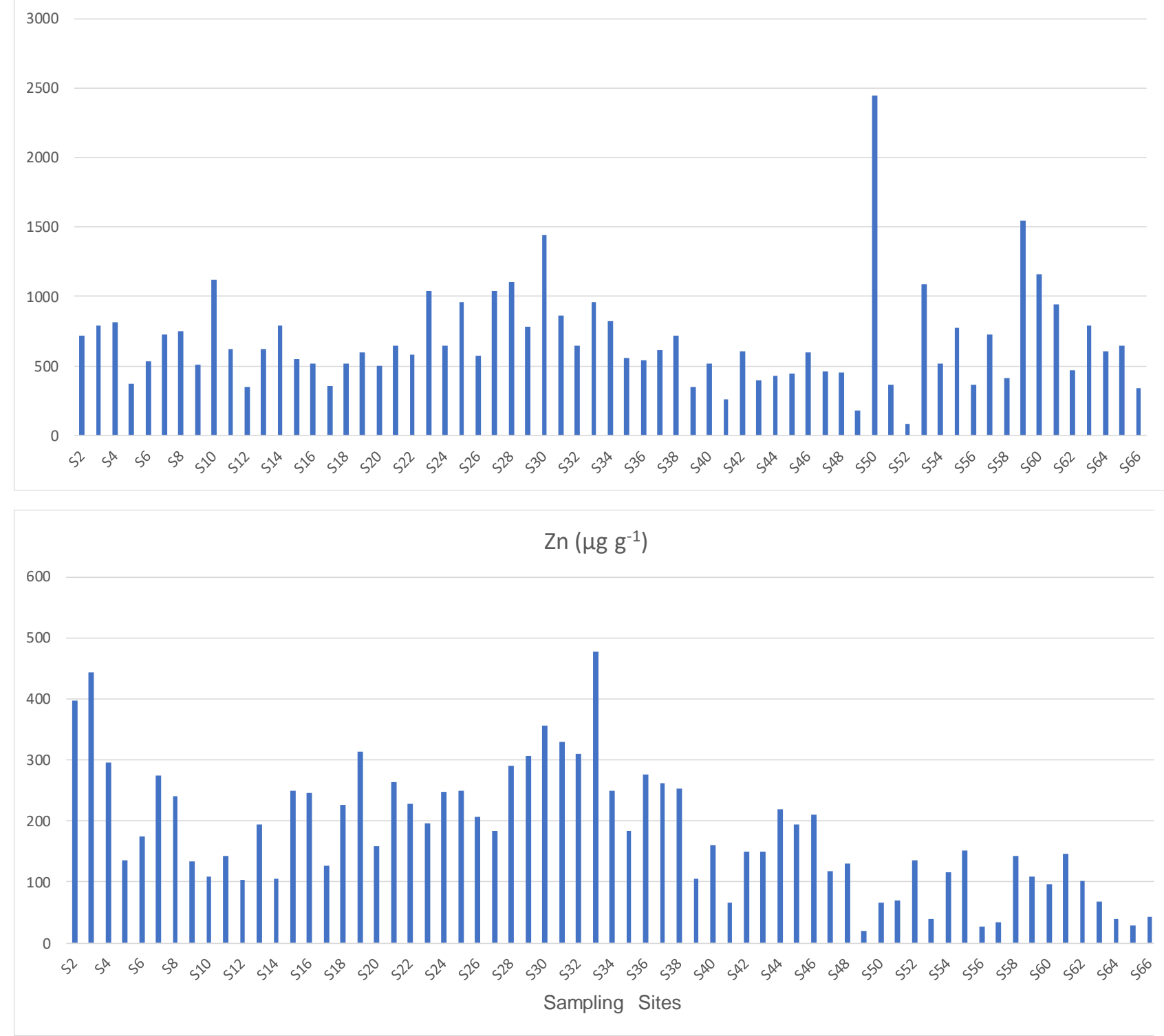

B.

Appendix 2. Concentration of non-essential elements by station. 


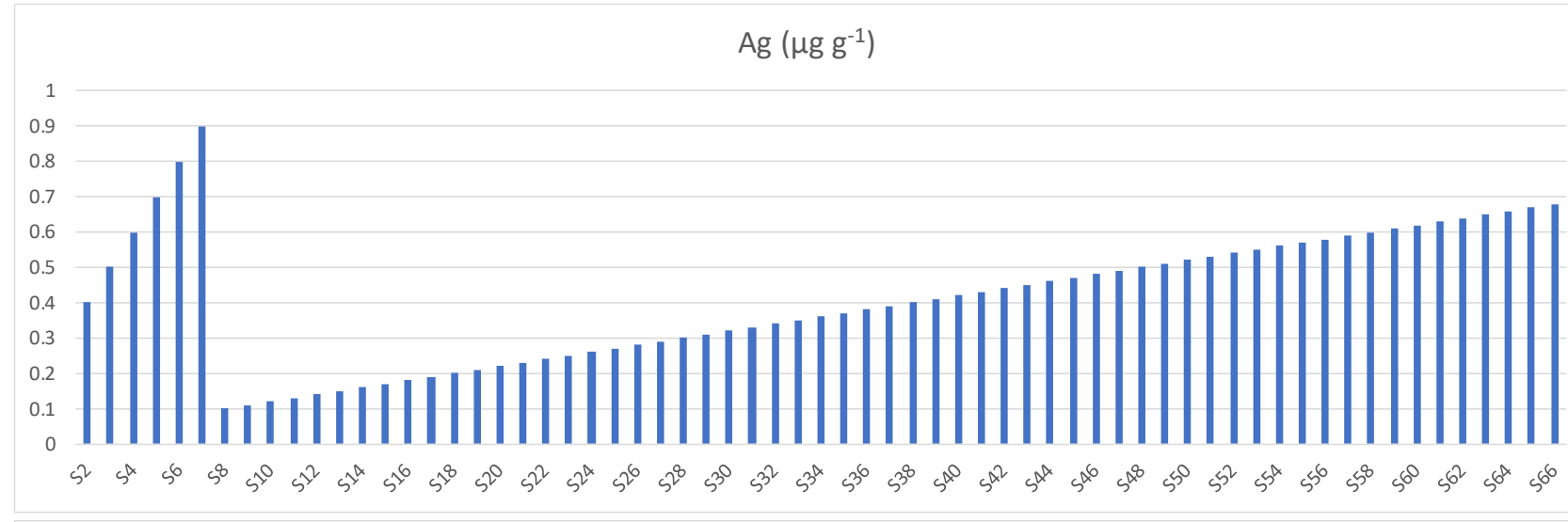

$\mathrm{Cd}\left(\mu \mathrm{g} \mathrm{g}^{-1}\right)$

3

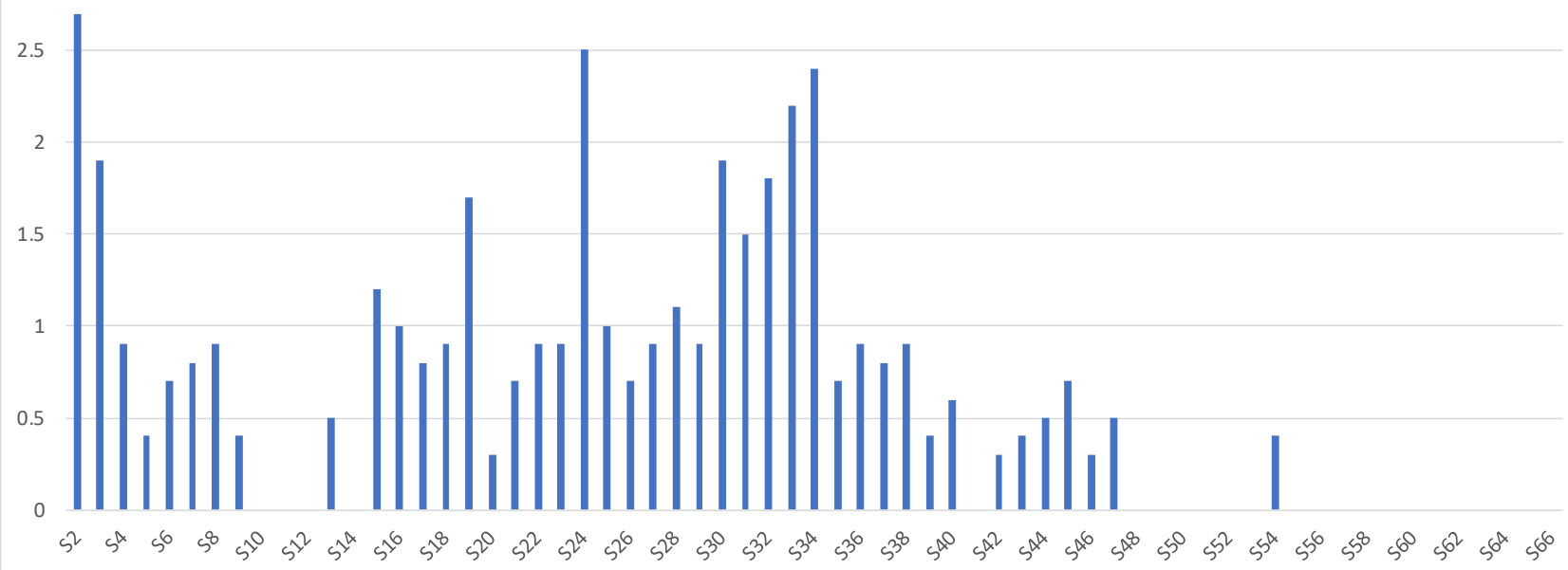

Co $\left(\mu \mathrm{g} \mathrm{g}^{-1}\right)$

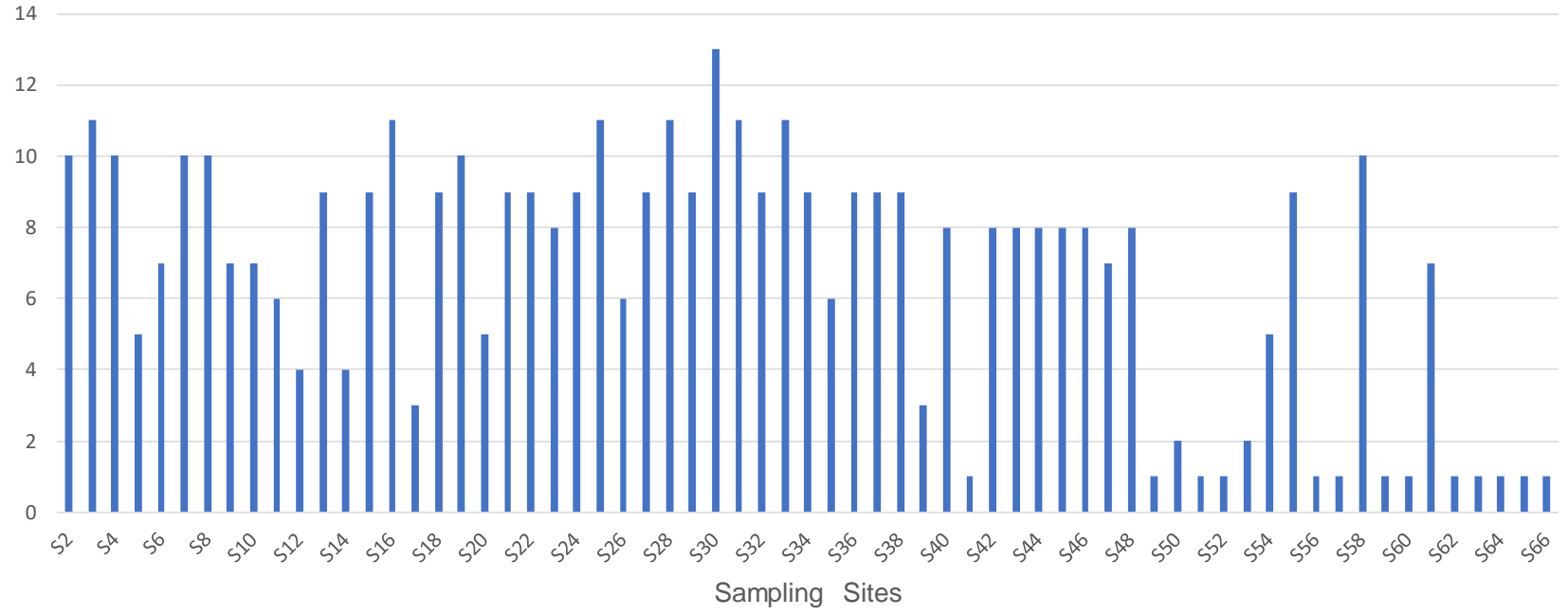

Appendix 3. Concentration of non-essential elements by station. 
Ni $\left(\mu g g^{-1}\right)$

35

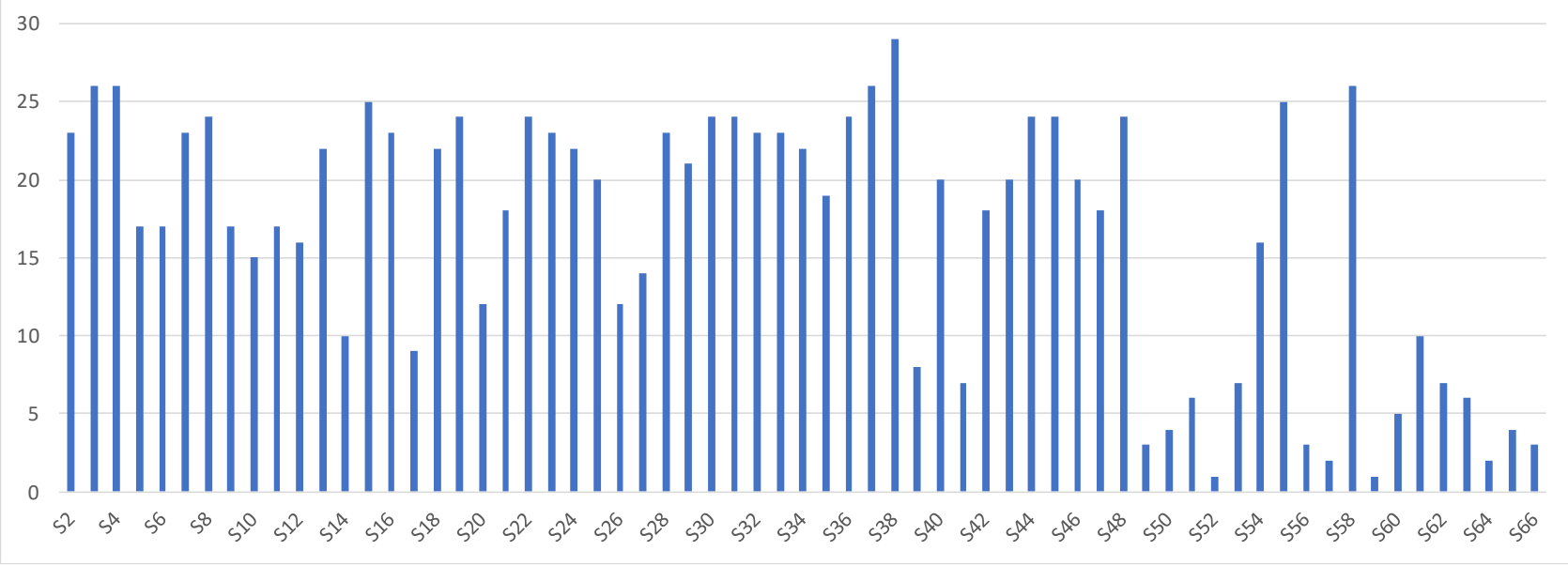

$\mathrm{Pb}\left(\mu \mathrm{g} \mathrm{g}^{-1}\right)$

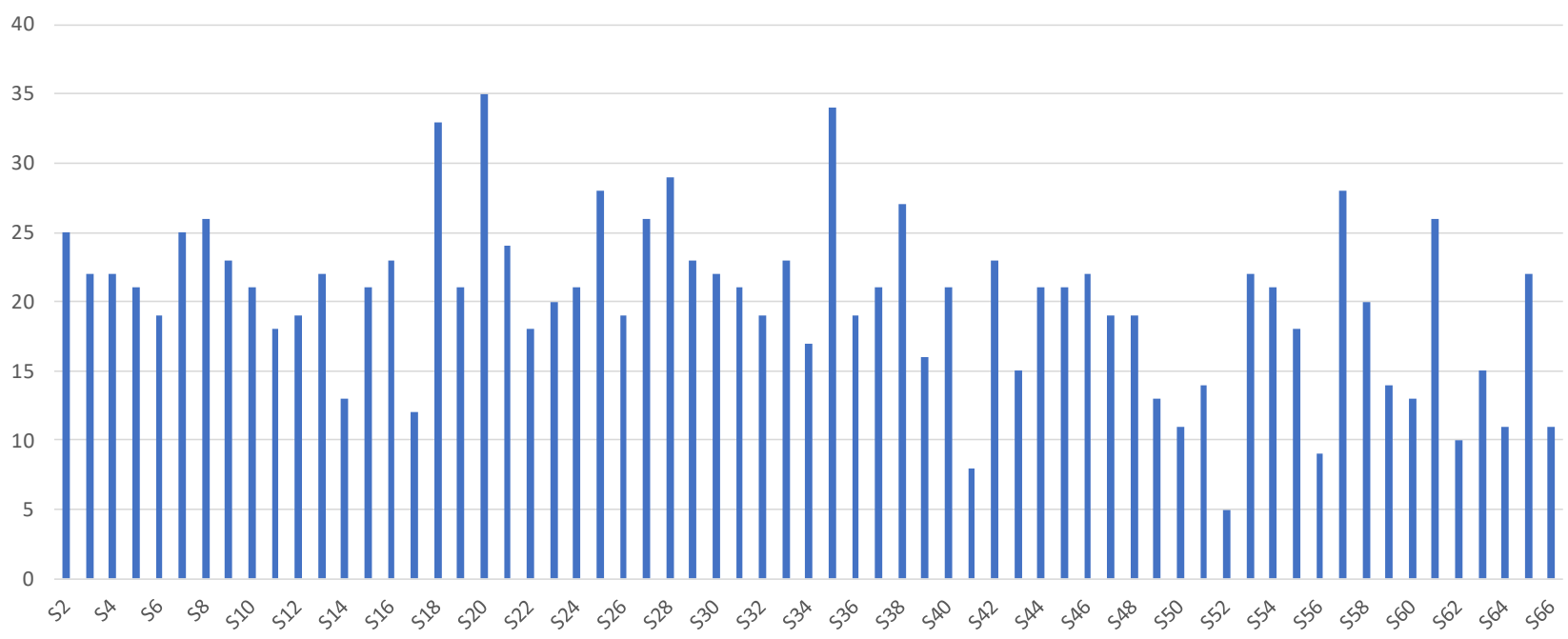

$\operatorname{Sr}\left(\mu \mathrm{g} \mathrm{g}^{-1}\right)$

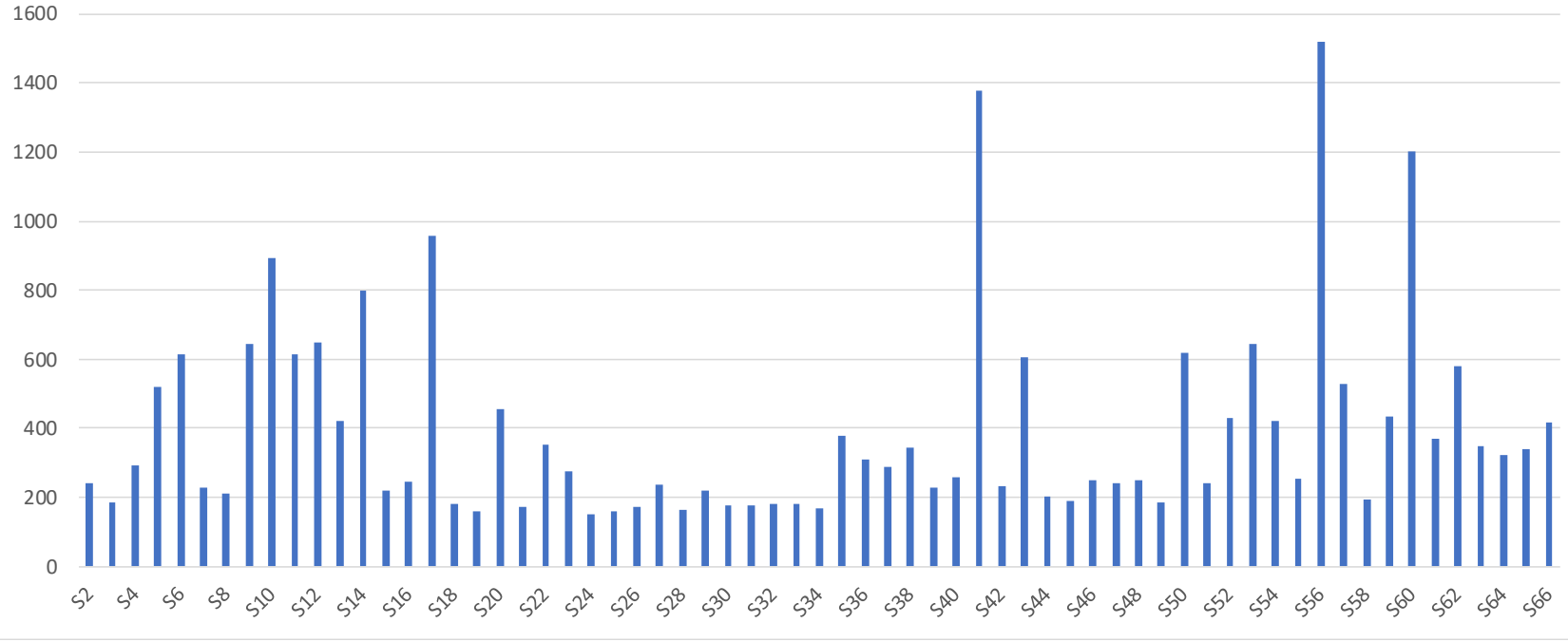

Appendix 4. Concentration of non-essential elements by station. 